\title{
Animal Models of Alzheimer Disease: Historical Pitfalls and a Path Forward
}

\author{
Sarah E. Cavanaugh ${ }^{1}$, John J. Pippin ${ }^{1}$ and Neal D. Barnard ${ }^{1,2}$ \\ ${ }^{1}$ Physicians Committee for Responsible Medicine, Washington, D.C., USA; ${ }^{2}$ Department of Medicine, George Washington \\ University School of Medicine and Health Sciences, Washington, D.C., USA
}

\begin{abstract}
Summary
Alzheimer disease $(A D)$ is a medically and financially overwhelming condition, and incidence rates are expected to triple by 2050. Despite decades of research in animal models of $A D$, the disease remains incompletely understood, with few treatment options. This review summarizes historical and current $A D$ research efforts, with emphasis on the disparity between preclinical animal studies and the reality of human disease and how this has impacted clinical trials. We provide a mechanism for shifting the focus of $A D$ research away from animal models to focus primarily on human biology as a means to improve the applicability of research findings to human disease. Implementation of these alternatives may hasten development of improved strategies to prevent, detect, ameliorate, and possibly cure this devastating disease.
\end{abstract}

Keywords: Alzheimer disease, animal experimentation, clinical research, research models, therapy

\section{Introduction}

Alzheimer disease (AD), the primary cause of dementia in the middle-aged and elderly, is a debilitating, ultimately fatal disease characterized by progressive neurological deterioration. In addition to the medical severity of the disease, the annual cost of AD care worldwide exceeds $\$ 600$ billion. Currently, more than 36 million people live with some form of dementia, and this number is expected to triple by 2050. In light of this frightening prospect, new and effective methods for preventing, detecting, and treating $\mathrm{AD}$ are desperately needed.

Over the last several decades, an abundance of research has been carried out, primarily in transgenic rodents, in an attempt to characterize the onset and course of $\mathrm{AD}$. A number of candidate therapeutics has shown great promise in these animal models. Unfortunately, these studies have rarely translated into clinical benefits for patients. Today, AD remains difficult to diagnose and ultimately incurable, with few treatment strategies for disease management. This review details historical and current $\mathrm{AD}$ research efforts, highlighting the results of clinical trials for potential therapeutics, as well as the disparity between preclinical animal studies and the reality of human disease. We discuss current standards for diagnosis of $\mathrm{AD}$, the limited options for treatment of the disease, and potential prevention strategies. Ultimately, we lay out a roadmap for shifting the focus of $\mathrm{AD}$ research away from animal models to focus primarily on human biology as a means to improve the applicability of research findings to human disease. Implementation of these alternatives may hasten development of improved strategies to prevent, detect, ameliorate, and possibly cure this devastating disease.

\section{Epidemiological and clinical characteristics of Alzheimer disease}

Dementia is a syndrome caused by central nervous system (CNS) disease and characterized by gradual decline of cognitive function (Alzheimer's Disease International, 2009; Fitzpatrick et al., 2005). Worldwide, an estimated 36.5 million people currently live with some form of dementia. This number is predicted to reach more than 65 million by 2030 and more than 115 million by 2050 (Obermeyer et al., 2012). The most common cause of dementia is Alzheimer disease (AD), representing 50-75\% of dementia cases (Alzheimer's Disease International, 2009). The number of people living with AD in the United States alone is expected to increase from 5.2 million in 2013 to 13.8 million in 2050 (Alzheimer's Association, 2013; Hebert et al., 2013).

Alzheimer disease was first described by Alois Alzheimer in 1906 , and is a fatal disease characterized by progressive loss of cognitive abilities (Wilkins and Brody, 1969). AD may be categorized into early and late onset. Early-onset AD typically begins between the ages of 30 and 60 years, and accounts for fewer than $5 \%$ of AD cases. The more common form, late-onset or spo- 
radic $\mathrm{AD}$, presents after the age of 65 (Irvine et al., 2008; Rossor et al., 1996). Forgetfulness and difficulties with routine tasks are typically the initial symptoms. As the disease progresses, AD patients develop more severe memory loss, speech impairment, visual and spatial deficits, and loss of coordination and fine motor control (Rossor et al., 1996; Obermeyer et al., 2012; Alzheimer's Disease Internatinal, 2009). In addition to the cognitive, sensory, and motor deficits caused by the progression of $\mathrm{AD}$, there are a number of behavioral and psychological symptoms related to dementia. These symptoms include agitation and aggression, wandering, disturbances in the sleep cycle, depression, anxiety, delusions and hallucinations (Ferri et al., 2004; de Vugt et al., 2005; Obermeyer et al., 2012). AD reduces the life expectancy of those affected, with an average survival time after diagnosis of 5-7 years (Fitzpatrick et al., 2005; Ganguli et al., 2005).

The single greatest risk factor for developing AD is age, with a risk of $10 \%$ for persons older than 65 years and nearly $50 \%$ for those older than 85 years (Rossor et al., 1996; Gatz et al., 2006; Chai, 2007). Onset of disease before age 65 is uncommon and suggests involvement of a genetic component. Autosomal dominant familial AD (FAD), which is typically an early onset $\mathrm{AD}$, has been linked to mutations in genes encoding presenilin1 (PSEN1), presenilin2 (PSEN2), and amyloid beta (A4) precursor protein (A $\beta P P)$ (Schellenberg et al., 1992; Sherrington et al., 1995; Levy-Lahad et al., 1995; Goate et al., 1991; Chartier-Harlin et al., 1991; Mullan et al., 1992). Inheritance of the apolipoprotein E type 4 allele (ApoE4) may increase the risk of developing sporadic late-onset $\mathrm{AD}$, though ApoE4 alone is neither necessary nor sufficient to cause AD (Strittmatter et al., 1993; Corder et al., 1993; Sadigh-Eteghad et al., 2012; Rossor et al., 1996).

In addition to being a devastating physical illness, AD places a dramatic emotional and economic burden on caretakers and the healthcare system. According to the Alzheimer's Association, eighty percent of care provided to individuals with $\mathrm{AD}$ is provided by unpaid caregivers such as family members and friends (Schulz and Martire, 2004; Schneider et al., 1999; Alzheimer's Association, 2013; Prince and Dementia Research, 2004). In 2012 alone, American caregivers provided approximately 17 billion hours of unpaid care to those with AD. The time spent providing this unpaid care is valued at an estimated \$216 billion (Alzheimer's Association, 2013). Additionally, more than sixty percent of $\mathrm{AD}$ caregivers "rate the emotional stress of caregiving as high or very high; more than onethird report symptoms of depression" (Alzheimer's Association, 2013; Zarit et al., 1980; Zarit et al., 1986; Cuijpers, 2005; Schulz and Beach, 1999). Due to the physical and emotional toll of caregiving, dementia caregivers in the United States had \$9.1 billion in additional health care costs of their own in 2012 (Alzheimer's Association, 2013). In 2010, the worldwide cost of providing care to individuals with $\mathrm{AD}$ and other forms of dementia reached more than $\$ 604$ billion (Obermeyer et al., 2012). The direct cost for AD care in the United States in 2013 is projected to be $\$ 203$ billion, including $\$ 142$ billion in Medicare- and Medicaid-related costs. With the number of people suffering from AD expected to triple by 2050, estimated cost of care is expected to reach more than $\$ 1$ trillion per year in the United States (Alzheimer's Association, 2013).

\section{Alzheimer disease pathology and basic science animal research}

A number of genetic mutations have been associated with the pathological changes that occur in the brain during the course of $\mathrm{AD}$, particularly in cases of FAD. In order to gain greater understanding of the progression of $\mathrm{AD}$, researchers have taken advantage of these known mutations by developing transgenic animals - primarily mice - who express these mutated proteins. Using both transgenic and natural models, scientists hope to extrapolate information regarding the development and progression of an AD-like disease in animals to what actually occurs in humans. The following section provides a brief overview of AD pathology and some of the most commonly used models, what they were designed to accomplish, and the limitations that have restricted their contribution to human health. Specific attributes of various models will be discussed in detail later.

On a cellular level, AD is associated with the development of beta-amyloid (A $\beta$ ) plaques and neurofibrillary tangles (NFT) within and surrounding neurons of the CNS (Glenner and Wong, 1984; Wood et al., 1986; Kosik et al., 1986). A $\beta$, a protein normally found in the healthy brain, is derived from A $\beta P P$ (Shoji et al., 1992). A $\beta P P$ is cleaved first by $\beta$-secretase (BACE1) at amino acids 1 and 11 (Cai et al., 2001). A second, carboxyterminal cleavage is then performed by the $\gamma$-secretase complex (composed of PSEN 1 and 2, nicastrin, and anterior pharynx-defective 1) (Wolfe, 2006). Depending on where A $\beta P P$ is cleaved by $\gamma$-secretase, one of two $A \beta$ isoforms may be released: $A \beta 1$ 40 or $A \beta 1-42 . A \beta 1-42$ is more prone to oligomerization and more readily forms the aggregates present in $\mathrm{AD}$ (Schroeter et al., 2003; Cai et al., 2001; Iwatsubo et al., 1994). Deposition of $\mathrm{A} \beta$ plaques in the brain is also associated with neuronal damage and activation of local astrocytes and microglia, resulting in localized inflammatory responses (Veerhuis, 2011; Eikelenboom and Stam, 1982; Eikelenboom et al., 1989; Eikelenboom and Veerhuis, 1996; Rosenberg, 2005). However, accumulation of $\mathrm{A} \beta$ plaques is not necessarily either a cause or a consequence of $\mathrm{AD}$, as plaques can be found in the brains of cognitively healthy individuals (Walsh et al., 2000).

NFT result from hyperphosphorylation and accumulation of tau protein, a microtubule-associated protein known to play a role in axonal growth and plasticity (Wood et al., 1986; Kosik et al., 1986). It is important to note that neither $A \beta$ plaques nor NFT are specific to AD, and both have been found in the brains of individuals with frontotemporal dementia (FTD), Parkinson disease, Huntington disease, Down syndrome, and amyotrophic lateral sclerosis, as well as in apparently normal brains (Masters et al., 1985; Ross and Poirier, 2004). What exactly triggers A $\beta$ plaque and NFT formation, how plaques and NFT are related (if at all), as well as how these traits contribute to AD symptoms, remains incompletely understood.

Development of transgenic mouse models of AD pathology has been a popular research method (Tab. 1). As one of the hallmarks of $\mathrm{AD}$, extracellular accumulation of $\beta$-amyloid peptides has been a common target (Hardy and Higgins, 1992; NIA, 1997). Three distinct mutations in A $\beta P P$ have been associated with development of FAD, named for the places in which they 
Tab. 1: Common mouse models of Alzheimer disease, relevant transgenes and mutations (if applicable), and the promoter under which transgenes are expressed

\begin{tabular}{|c|c|c|c|c|}
\hline Model & Transgene(s) & Mutation(s) & Promoter & Reference \\
\hline PDAPP & hAPP & V717F & PDGF & Games et al., 1995 \\
\hline $\mathrm{H} 6$ & hAPP & $\mathrm{N} / \mathrm{A}$ & PDGF & Wyss-Coray et al., 1997 \\
\hline J9 & hAPP & $\mathrm{N} / \mathrm{A}$ & PDGF & Chin et al., 2005 \\
\hline J20 & hAPP & N/A & PDGF & Chin et al., 2005 \\
\hline $\operatorname{Tg} 2576$ & hAPP & K670N, M671L & Hamster prion protein & Hsiao et al., 1996 \\
\hline APP23 & hAPP & K670N, M671L & Thy -1.2 & Sturchler-Pierrat et al., 1997 \\
\hline C3-3 & $\begin{array}{l}\text { Chimeric human/ } \\
\text { murine APP }\end{array}$ & K670N, M671L & Mouse prion promoter & Borchelt et al., 2007 \\
\hline CRND8 & hAPP & K670N, M671L, V717F & Hamster prion promoter & Chishti et al., 2001 \\
\hline APPDutch & hAPP & E693Q & Thy-1.2 & Herzig et al., 2004 \\
\hline ARC6/ARC48 & hAPP & E22G & PDGF & Cheng et al., 2004 \\
\hline C3-3 x PSEN1 & $\begin{array}{l}\text { Chimeric human/ } \\
\text { murine APP, hPSEN1 }\end{array}$ & $\begin{array}{l}\text { APP K670N, M671L; } \\
\text { PSEN A246E }\end{array}$ & $\begin{array}{l}\text { Mouse prion promoter } \\
\text { (APP, PSEN1) }\end{array}$ & Borchelt et al., 2007 \\
\hline PSAPP & hAPP, hPSEN1 & $\begin{array}{l}\text { APP K670N, M671L; } \\
\text { PSEN M146L }\end{array}$ & $\begin{array}{l}\text { Hamster prion protein } \\
\text { (APP), } \\
\text { HMG-CoA reductace } \\
\text { (PSEN) }\end{array}$ & McGowan et al., 1999 \\
\hline $\operatorname{APP}_{\mathrm{SL}} \mathrm{PS}_{\mathrm{M} 146 \mathrm{~L}}$ & hAPP, hPSEN1 & $\begin{array}{l}\text { APP K670N, M671L, } \\
\text { V717I; PSEN M146L }\end{array}$ & $\begin{array}{l}\text { Thy }-1 \text { (APP), } \\
\text { HMG-CoA reductace } \\
\text { (PSEN) }\end{array}$ & Langui et al., 2004 \\
\hline $\mathrm{APP}_{\mathrm{SL}} P S 1_{\mathrm{ki}}$ & hAPP, hPSEN1 & $\begin{array}{l}\text { APP M233T, L235P; } \\
\text { PSEN1 M233T, L235P }\end{array}$ & Thy1 (APP) & Casas et al., 2004 \\
\hline 5XFAD & hAPP, hPSEN1 & $\begin{array}{l}\text { APP K670N, M671L, } \\
\text { I716V, V717I; } \\
\text { PSEN1 M146L, L286V }\end{array}$ & Thy1 & Oakley et al., 2006 \\
\hline hBACE1/hAPP & hAPP, hBACE1 & $\mathrm{N} / \mathrm{A}$ & Thy1 (BACE1, APP) & Bodendorf et al., 2002 \\
\hline Htau & hTau & mTauKO & Tau, Thy 1 & Andorfer et al., 2003 \\
\hline TauP301L & hTau & P301L & Thy 1.2 & Gotz et al., 2001 \\
\hline Tau V337M & hTau & V337M & PDGF & Tanemura et al., 2002 \\
\hline Tau P301S & hTau & P301S & Thy1.2 & Allen et al., 2002 \\
\hline Tau G272V, P301S & hTau & G272V, P301S & Thy1.2 & Schindowski et al., 2006 \\
\hline $3 x \operatorname{Tg}-A D$ & hAPP, hPSEN1, hTau & $\begin{array}{l}\text { APP K670N, M671L; } \\
\text { PSEN1 M146V; tau P301L }\end{array}$ & Thy1.2 (APP, Tau) & Oddo et al., 2003 \\
\hline
\end{tabular}

were discovered: Swedish (K670N/M671L), London (V717I) and Indiana (V717F) (Duyckaerts et al., 2008; Chartier-Harlin et al., 1991; Goate et al., 1991). Numerous transgenic mouse lines have been developed which express human $\mathrm{A} \beta \mathrm{PP}(\mathrm{hA} \beta \mathrm{PP})$ proteins with one or more of these FAD mutations. Generally speaking, in these mice extracellular deposits of $A \beta$ develop at various time points during the course of the animal's life. Moreover, there is evidence of inflammation in the brain, and the animals display cognitive and behavioral deficits compared to wild-type animals (Games et al., 1995; Chishti et al., 2001;
Mucke et al., 2000; Sturchler-Pierrat et al., 1997; Borchelt et al., 1997; Cheng et al., 2004).

Mutations in the PSEN proteins are associated with development of early-onset AD in humans (Rogaev et al., 1995; Sherrington et al., 1995; Perez-Tur et al., 1995). Mice expressing mutated human PSEN1 (M146L or M146V) or PSEN2 alone do not develop A $\beta$ plaques (Mattson et al., 2001; Oyama et al., 1998; Sawamura et al., 2000). However, doubly transgenic mice expressing both mutated A $\beta$ PP and PSEN1 develop A $\beta$ plaques at a much earlier age than mice expressing mutated $A \beta P P$ 
alone, with more severe $\mathrm{A} \beta$ plaque formation, neuroinflammation, and cognitive decline (Casas et al., 2004; Borchelt et al., 1997; Blanchard et al., 2003; Duff et al., 1996; Holcomb et al., 1998; McGowan et al., 1999). Expression of five genetic mutations associated with FAD (AßPP K670N/M671L (Swedish), I716V (Florida), V717I (London), PS1 M146L and L286V) in the 5XFAD mouse line results in significant acceleration of $A \beta$ accumulation (Oakley et al., 2006). Similarly, the $\beta$-secretase BACE1 plays an important role in both homeostatic neuronal function and the pathogenesis of AD (Harrison et al., 2003). Mice expressing both BACE1 and human A $\beta$ PP exhibit enhanced kinetics of $A \beta$ formation, increased levels of $A \beta$ peptides, and more numerous plaques than $\mathrm{A} \beta \mathrm{PP}$-transgenic mice (Rockenstein et al., 2005).

Use of transgenic mouse models of amyloid pathology has led to new insights regarding the processing of $A \beta$ and the role of soluble $\mathrm{A} \beta$ oligomers in the pathogenesis of AD (Schaeffer et al., 2011; Morrissette et al., 2009; Cheng et al., 2007; Lesne et al., 2006). For example, in many APP transgenic mice, pathological and functional changes occur before the appearance of amyloid plaques (Schaeffer et al., 2011).

While many of these transgenic mice develop $\mathrm{A} \beta$ plaque pathology and cognitive impairment, they do not address the other hallmark of AD - NFT formation. To address the role of tau protein hyperphosphorylation and NFT in the pathogenesis of AD, several mouse models have been developed that overexpress either wild-type or mutated human tau protein. Notably, tau protein mutations are associated with frontotemporal dementia, but not with AD (Duyckaerts et al., 2008). Introduction of human tau proteins containing FTD mutations resulted in NFT formation (Gotz et al., 2001; Lewis et al., 2000; Tanemura et al., 2002; Allen et al., 2002). Tau protein containing both G272V and P301S mutations resulted in both NFT formation and severe cognitive deficits (Schindowski et al., 2006). In an effort to model NFT pathology which is relevant to AD rather than FTD, tau knockout mice were crossed with mice expressing human genomic tau protein, resulting in mice expressing human but not murine tau protein (htau). However, these mice express minimal NFT pathology (Andorfer et al., 2003; Duff et al., 2000; Salkovic-Petrisic et al., 2013).

In an attempt to replicate both neuroanatomical aspects of AD pathology - that is, both A $\beta$ plaques and NFT - a triple transgenic mouse model was developed. Triple transgenic mice express human A $\beta$ PP with the Swedish mutation, PSEN (M146V) and tau protein (P301L). Unlike the mouse models discussed thus far, these mice develop both A $\beta$ plaques and NFT with tau pathology. Additionally, the mice develop other pathological and behavioral characteristics similar to AD: gliosis, synaptic damage and memory impairment (Oddo et al., 2003). These mice further support the notion that soluble $\mathrm{A} \beta$ oligomers are toxic, as neuronal and functional deficits appear prior to plaque or NFT formation (Morrissette et al., 2009; Schaeffer et al., 2011).

While the transgenic mice described above have been very widely used in AD research, a number of other transgenic and non-transgenic animal models have been developed as well. The senescence-accelerated mouse strains (SAMP) were developed through selective breeding rather than transgenic technology.
These animals develop $A \beta$ deposition with cognitive impairment by 6 months of age (Del Valle et al., 2010). The rat is, in general, the mostly commonly used animal in the field of neuroscience research. Rats expressing transgenes similar to those used in transgenic mouse models have been developed, though few of them have actually been shown to lead to $A \beta$ deposition and/or NFT pathology. A transgenic rat model (TgF344-AD) was recently developed which expresses human A $\beta$ PP with the Swedish mutation and PSEN (PS1 $\triangle E$ 9) genes, leading to development of plaques and tau pathology (Cohen et al., 2013). Targeting rat nerve growth factor receptor with a monoclonal antibody conjugated to saporin (192 IgG-saporin) results in loss of cholinergic neurons and some cognitive impairment (Wiley et al., 1991). Evidence suggesting a connection between AD and impaired brain insulin signaling led to the development of a model in which rats are treated with streptozotocin (STZ), a drug that targets insulin-producing beta cells of the pancreas for destruction (Grunblatt et al., 2004; de la Monte and Wands, 2005). Rats treated with STZ develop memory and learning deficits, progressive loss of cholinergic neurons, and neurodegeneration. There have been mixed reports regarding changes to the $\mathrm{A} \beta$ peptide and tau protein in STZ-treated rat brains (Grunblatt et al., 2004; Prickaerts et al., 1999; Salkovic-Petrisic et al., 2006).

Unlike mice and rats, rabbits share an identical $\mathrm{A} \beta$ peptide sequence with humans, though they do not spontaneously develop any AD-like disease (Johnstone et al., 1991). However, wild type rabbits fed high cholesterol diets have been shown to develop A $\beta$ deposition, tau pathology, neuronal loss, and cognitive impairment (Sparks and Schreurs, 2003). Interestingly, the increase in levels of $A \beta$ deposition in the brain of cholesterol-fed rabbits is dependent on the presence of trace levels of copper in the drinking water, suggesting this particular metal may play a role in progression of AD (Woodruff-Pak, 2008; Woodruff-Pak et al., 2007). For this reason, researchers have believed rabbits to be useful in testing metal chelators as potential neuroprotective treatments (Ghribi et al., 2006; WoodruffPak et al., 2007).

Dogs have come to be considered a useful model of AD for a number of reasons. In addition to homology between a number of canine and human A $\beta$ PP processing proteins, dogs, like humans, develop intricate social lives and are excellent readers of human communication and social interaction (Johnstone et al., 1991; Hare and Tomasello, 2005). As a result, cognitive function of canines can be measured not only by level of disorientation and learning deficits, but by interaction with humans as well (Sarasa and Pesini, 2009). Moreover, aging canines have been shown to develop cognitive symptoms similar to $\mathrm{AD}$ in humans (Landsberg, 2005; Opii et al., 2008; Cummings et al., 1996b; Tapp et al., 2003; Head et al., 1995). The brains of aged canines have also been shown to develop $A \beta$ plaques, though they do not develop NFT. The extent of $A \beta$ plaque pathology correlates with some measure of cognitive impairment, though, as in humans, $A \beta$ plaque pathology has been identified in canines without any apparent cognitive symptoms (Sarasa and Pesini, 2009). Many treatment strategies in preclinical testing have been applied to canines (Head et al., 1998, 2000; Cummings et al., 1996a; Colle et al., 2000; Hou et al., 1997). 
Nonhuman primates (NHP) are long-lived species and are the genetically and physiologically closest relatives to humans. The structure and organization of the NHP brain is similar to that of humans, and the sequence of NHP A $\beta$ PP is identical to that of humans. Several species of NHP develop age-related neurodegenerative conditions accompanied by cognitive deficits (Martin et al., 1994; Lemere et al., 2008; Gearing et al., 1997; Schultz et al., 2000; Bons et al., 2006). Specifically, this neurodegeneration is associated with brain atrophy, abundant amyloid plaques, and loss of cholinergic neurons (Voytko, 1998). A few species develop tau pathology in addition to amyloid plaque burden (Sarasa and Pesini, 2009). Interestingly, despite these similarities between humans and NHP, some researchers are proposing development of transgenic NHP for the purpose of studying AD (Chen et al., 2012; Chan and Yang, 2009).

\section{Correlations between animal models of AD and human AD}

Despite the availability of a variety of AD animal models across several species, use of these models has rarely translated into health benefits for humans with AD. This is almost certainly due to the imperfect replication of human AD in any other animal species, as well as species-specific functions of structurally identical genes and responses to targeted therapies. To date, no single animal model has exhibited both neuropathological and behavioral symptoms characterizing human AD. A variety of intrinsic differences between animal models of AD and human disease are responsible for these shortcomings (Duyckaerts et al., 2008).

Perhaps the most obvious divergence from human disease in transgenic animal models is the artificial nature of transgenic technology. First, the transgenic animals developed for AD research express human genes containing mutations associated with FAD. However, a very high percentage of $\mathrm{AD}$ cases are sporadic and not associated with any particular genetic mutation. As a result, the animal models that have been developed to model $\mathrm{AD}$ are not clearly relevant to the dominant form of AD occurring in humans (Alzheimer's Association, 2013; Chai, 2007; Alzheimer's Disease International, 2009; Rossor et al., 1996). Transgenic animals in AD research express human ADrelated genes that have been artificially introduced into an embryo under control of a promoter. As a result, there is no way to control such key factors as where in the genome the transgene will insert, how many copies will be inserted, and the manner in which the inserted gene will undergo transcription, RNA processing, and protein post-translational modification (Davis et al., 2012; Geghman and Li, 2011; Toman et al., 1999). Moreover, the tissue in which the gene is expressed, as well as the timing and abundance of expression, are largely dependent on the promoter introduced with the gene (Duyckaerts et al., 2008). Many of the available transgenic mouse models utilize different promoters, contributing to the discrepancies in results among animal studies. Finally, because transgenes in rodent models of $\mathrm{AD}$ are foreign (i.e., human), high expression of these genes may trigger unpredictable responses or defense mechanisms in cells (Duyckaerts et al., 2008; Davis et al., 2012; Thyagarajan et al., 2003). This may confound interpretation of results from experiments utilizing AD rodent models, as it is not always clear whether a particular pathology is due to AD-like disease or some developmental abnormality resulting from the overexpression of a human gene in a rodent cell.

Beyond the artificial nature of transgenic rodent models, mice and rats developing AD-like symptoms and pathology do not faithfully recapitulate human $\mathrm{AD}$ in any model. Single-transgenic rodent models exhibit very little neuronal loss during the course of disease, whereas human AD is characterized by progressive loss of cholinergic neurons (Duyckaerts et al., 2008; Calhoun et al., 1998; Lewis et al., 2000). Conversely, in a number of the double - or triple - transgenic mouse models, moderate to severe neuronal loss has been observed, primarily in the hippocampus (Irizarry et al., 1997; Ishihara et al., 1999; Casas et al., 2004; Schmitz et al., 2004; Urbanc et al., 2002). However, the sheer variability in results from these different model systems makes it difficult to extrapolate data for application to human disease. Moreover, AD in humans results in significant atrophy of the brain, particularly in the entorhinal cortex, hippocampus, and amygdala (Duyckaerts et al., 2008). While brain atrophy is observed in transgenic mice, it occurs very early in life (by three months of age) and prior to accumulation of $\mathrm{A} \beta$ (Dodart et al., 2000; Gonzalez-Lima et al., 2001; Redwine et al., 2003; Valla et al., 2006). One possible explanation is that brain atrophy in transgenic animals is a developmental defect, unrelated to ADlike pathology (Duyckaerts et al., 2008).

Another important discrepancy between rodent and human $\mathrm{AD}$ pathology is the localization of $\mathrm{A} \beta$ plaques and NFT. In humans, $A \beta$ deposits begin exclusively in the neocortex. Pathology then extends into allocortical brain regions, such as the hippocampus. Regions of the diencephalon, where the thalamus and hypothalamus are located, as well as the striatum and cholinergic nuclei of the basal forebrain are affected next. Finally, in the late stages of disease, $A \beta$ pathology can be detected in regions of the brain stem and the cerebellum. The plaques that are seen in the cerebellum are "diffuse" while the plaques that are thought to be most pathogenic, and the ones specifically required for a diagnosis of $\mathrm{AD}$, are "neuritic" plaques.

In mouse models of $\mathrm{AD}$, however, the spatial distribution of pathology depends largely on the promoter used to drive expression of the transgenes (Duyckaerts et al., 2008; Davis et al., 2012). It is worth noting that even with ubiquitous neuronal expression in some mouse models (e.g., $\operatorname{tg} 2576$ ) there is still a remarkable regional specificity, with plaques primarily in hippocampus and cortex. As discussed previously, many of the commonly used models of AD utilize a variety of different promoters, resulting in variation in pathological topography. While canine $\mathrm{A} \beta$ pathology appears largely in the cortex and hippocampus (similar to humans), the brain stem, cerebellum, entorhinal cortex, amygdala, basal ganglia and olfactory bulbs are largely unaffected (Hou et al., 1997; Head et al., 2000). Aged rhesus macaques exhibit loss of cholinergic neurons, much like humans affected by $\mathrm{AD}$, but the cortex of the macaque brain remains largely unaffected by AD-like pathology (Rapp and Amaral, 1992; Siddiqi and Peters, 1999). 
While differences in the relative distribution of $A \beta$ deposits throughout the brain are cause for concern when considering animal models, another important distinction between human disease and animal models is the physical nature of the $\mathrm{A} \beta$ peptide itself. Murine A $\beta$ aggregates demonstrate immunoreactivity with human $A \beta$-specific antibodies and stain similarly with thioflavin-S and Congo red (Duyckaerts et al., 2008). However, there are a number of significant differences between human and animal $\mathrm{A} \beta$ plaques. In humans, $\mathrm{A} \beta$ peptides are the primary components of so-called senile plaques (Roher et al., 1993; Sergeant et al., 2003). Multiple different isoforms of $A \beta$ are present in these plaques, including $A \beta_{1-40}, A \beta_{1-42}$, and numerous $N$ truncated peptides (Sergeant et al., 2003). Moreover, these peptides undergo a number of post-translational modifications, such as isomerization, racemization, pyroglutamyl formation, oxidation, and covalent linkage of A $\beta$ dimers (Kuo et al., 2001). The cumulative effect of these modifications results in a peptide that is largely insoluble. In mice, $\mathrm{A} \beta$ deposits are compact and laminar, and the murine $\mathrm{A} \beta$ peptide is completely soluble in solutions containing the denaturing agent sodium dodecyl sulfate (Kuo et al., 2001; Kalback et al., 2002). This is likely due to the lack of post-translational modification of $A \beta$ in the mouse model (Kuo et al., 2001). As Kuo et al. note, "It is possible that the processing required to create authentic AD plaques cannot occur in transgenic animals because either the necessary enzyme homologs are not present or the elevated pace of amyloid deposition simply precludes the prerequisite maturational reactions," thus underscoring another serious limitation of transgenic animal models (Kuo et al., 2001).

In the canine model of $\mathrm{AD}, \mathrm{A} \beta$ deposits tend to be diffuse and fibrillar, which only resembles early stages of AD in the human brain (Torp et al., 2000; Cotman and Head, 2008). Despite their close phylogenetic relationship to humans, NHP exhibit significant differences in $A \beta$ plaque characteristics as well. In aged macaques, vascular $A \beta$ deposits stain strongly against $A \beta_{1 \text { - }}$ 42 , while both $A \beta_{1-40}$ and $A \beta_{1-42}$ are present in human senile plaques (Nakamura et al., 1995; Kanemaru et al., 1996). Additionally, aged macaques possess a significantly greater ratio of $\mathrm{A} \beta_{1-40}$ to $\mathrm{A} \beta_{1-42}$ than human patients with $\mathrm{AD}$, suggesting that NHP may undergo fundamental differences in amyloid processing (Gearing et al., 1994, 1996).

As previously discussed, formation of $\mathrm{A} \beta$-containing plaques represents only a portion of the pathological changes that occur during the course of AD. Hyperphosphorylation of tau protein, leading to the development of NFT, is a second important hallmark of AD. To date, no transgenic mouse model, and only a single rat model, has been shown to develop both $\mathrm{A} \beta$ plaques and NFT. Several of the A $\beta$ transgenic mouse lines develop hyperphosphorylation of tau protein, but they do not develop NFT (Blanchard et al., 1997; Lazarov et al., 2007; Masliah et al., 2001; Shukkur et al., 2006). This underscores both the variability among transgenic models and the incomplete representation of human disease in these animals. Transgenic mice expressing normal human tau protein isoforms exhibit hyperphosphorylation of tau protein, but not NFT formation (Brion et al., 1999; Duff et al., 2000; Gotz et al., 1995; Ishihara et al., 1999; Probst et al., 2000; Spittaels et al., 1999). One exception to this is a transgenic mouse line than expresses human tau protein, but not mouse tau protein, resulting in NFT formation and implying that mouse tau protein prevents formation of NFT (Andorfer et al., 2003). This is likely due to expression of different tau protein isoforms in each species (Duyckaerts et al., 2008). NFT formation has been observed in several other transgenic mouse models in which a mutated human tau protein has been introduced (Gotz et al., 2001; Allen et al., 2002; Lewis et al., 2000; Tanemura et al., 2002; Schindowski et al., 2006). It is important to note that mutations in tau protein are not associated with human AD (Duyckaerts et al., 2008; Spillantini et al., 1998). Additionally, expression of mutated tau protein has led to formation of NFT in spinal motor neurons in mice, a phenomenon that does not occur in human AD (Lewis et al., 2000).

Despite being touted as an excellent model of human AD, canine brains tend not to exhibit tau pathology and NFT formation (Papaioannou et al., 2001; Wegiel et al., 1998; Satou et al., 1997; Pugliese et al., 2006). Tau pathology can be detected in the brains of only some species of NHP (Schultz et al., 2000; Lemere et al., 2008; Rosen et al., 2008). Importantly, when tau pathology does occur in NHP, it is found both in neurons and glial cells in various parts of the brain, an occurrence not associated with human AD (Kiatipattanasakul et al., 2000).

The presence of $\mathrm{A} \beta$ plaques provides stimuli to surrounding astrocytes and microglia, resulting in induction of localized immune responses in the human $\mathrm{AD}$ brain. $\mathrm{A} \beta$ is capable of activating complement and inducing expression of proinflammatory cytokines such as IL- $1 \beta$, IL- 6 , TNF- $\alpha$, and some chemokines (Eikelenboom and Veerhuis, 1996; Rubio-Perez and Morillas-Ruiz, 2012; Rosenberg, 2005; Akiyama et al., 2000). In mouse models of $\mathrm{AD}$, however, there have been conflicting reports regarding the nature of the inflammatory response to $A \beta$. Studies by different groups using the same transgenic mouse line have demonstrated different profiles of proinflammatory cytokine expression in the region of plaques (Benzing et al., 1999; Matsuoka et al., 2001; Mehlhorn et al., 2000). Moreover, a direct comparison of inflammation in transgenic mouse brains and brains from AD patients revealed an overall less profound inflammatory response in the mouse model (Schwab et al., 2004).

Finally, it is essential to note that animal models of AD are chosen or designed primarily on the basis of cognitive decline and AD-like pathology (specifically, the presence of plaques and/ or tangles). However, the exact cause of neuronal dysfunction and death resulting in cognitive decline remains unclear. In human $\mathrm{AD}$, the abundance of fibrillar $\mathrm{A} \beta$ plaques correlates poorly with the severity of dementia, though NFT burden may correlate to disease progression (Dickson et al., 1995; Terry et al., 1991; Bierer et al., 1995). Rather, recent data suggest that soluble A $\beta$ oligomers, which precede extracellular deposition of the protein and plaque formation, are responsible for synaptic dysfunction in the AD brain (Walsh and Selkoe, 2007). Even in mouse models, it has been reported that cognitive decline is evident prior to deposition of $A \beta$ plaques in the CNS (Westerman et al., 2002; Wu et al., 2004; Moechars et al., 1999; Hsia et al., 1999; Chapman et al., 1999). It is likely, then, that detection and treatment of $\mathrm{AD}$ prior to deposition of plaques and presentation of cognitive 
symptoms is necessary. However, because we do not understand the earliest stages of AD as it occurs in the human brain, there is no way to accurately model it in an animal such that it will readily translate into therapeutic benefit in patients.

It is clear that there are fundamental differences between human $\mathrm{AD}$ and the pathology present in animal models. Among these differences are characteristics of $A \beta$ peptide itself and plaque formation, concurrent presence of $A \beta$ and NFT, gross localization of pathology, and properties of the resulting immune response. Variation in the principal pathology of AD, combined with the lack of clarity regarding what actually causes AD, render animal models problematic for uncovering disease mechanisms and new therapeutics for the benefit of human health.

\section{Preclinical drug development research for Alzheimer disease}

A great deal of preclinical drug development research has been performed, or is ongoing, to shed light on AD risk factors and prevention, and to develop improved therapeutics. Numerous animal models have been used to develop diverse potential therapeutics targeting multiple different aspects of AD pathology. The following section briefly summarizes several of the different categories of potential therapeutics, their intended targets, and how they have fared in preclinical animal tests.

One of several neurodegenerative pathologies associated with $\mathrm{AD}$ is the loss of cholinergic neurons. These neurons produce the neurotransmitter acetylcholine, the loss of which is associated with development of memory deficits in AD. Acetylcholinesterase, the enzyme that hydrolyzes acetylcholine, has been observed to co-localize with $A \beta$ aggregates in the brain and to enhance the aggregation of $A \beta$ in vitro (Inestrosa et al., 1996). Inhibition of acetylcholinesterase has become an attractive drug target, and a number of candidate drugs have been tested in AD transgenic mice. Donepezil significantly enhanced cognitive performance in mice expressing mutated human A $\beta$ PP (Van Dam et al., 2008). Donepezil, as well as galantamine and tacrine, other acetylcholinesterase inhibitors, improved short-term memory and attention deficits induced by scopolamine in rats (Kirkby et al., 1996; Bores et al., 1996). Additionally, galantamine reversed cognitive deficits in mice who had received lesions to a region of the brain involved in memory (Sweeney et al., 1988; Sweeney et al., 1989). Ispronicline improved cognition and memory in mice with a favorable safety profile in rodents and dogs (Lippiello et al., 2006; Gatto et al., 2004). Finally, phenserine has been shown to significantly improve cognition in both rodent and canine models of AD (Haroutunian et al., 1997; Klein, 2007; Lilja et al., 2013a,b; Patel et al., 1998).

Modulation of nicotinic and muscarinic receptors can modify acetylcholine metabolism as well. M1 muscarinic receptor agonists talsaclidine, AF-102B and AF-267B (NGX-267) improved cognitive outcomes in mouse, rabbit and lemur models of AD. These drugs reduced $A \beta$-related oxidative stress and apoptosis in neurons and decreased tau protein hyperphosphorylation (Fisher et al., 2002a,b). Similarly, the nicotinic receptor agonist ABT-089 has resulted in improvements in cognitive function in both rats and NHP (Sullivan et al., 1997; Decker et al., 1997; Rueter et al., 2004).

Memantine, a N-methyl-D-aspartate (NMDA) receptor antagonist, improved cognitive ability in mouse models of AD. NMDA receptors are involved in synaptic plasticity and synapse formation, which play important roles in memory and learning (Minkeviciene et al., 2004; Mayer and Westbrook, 1987). In several studies involving cognitive impairment in rats, memantine reversed memory and learning deficits (Zajaczkowski et al., 1996; Wenk et al., 1997; Barnes et al., 1996). On a cellular level, rat neurons were protected from $A \beta$-related apoptosis and neurodegeneration when treated with memantine (Miguel-Hidalgo et al., 2002). These findings are consistent with evidence that hyperactivation of NMDA receptors may contribute to neuronal injury in AD (Danysz and Parsons, 2003).

The AChEI drug tacrine, when produced as the dimer bis(7)tacrine, reduced generation of $A \beta$ by blocking NMDA receptors as well as directly inhibiting the $\beta$-secretase involved in $A \beta$ processing in in vitro studies (Fu et al., 2008). Treatment with bis(7)-tacrine also reduced the severity of memory deficit in rat models of cognitive impairment (Liu et al., 2000). Moreover, bis(7)-tacrine is able to protect neurons from $A \beta$-related apoptosis by modulating calcium channel activity (Fu et al., 2006). Two drugs used to treat type 2 diabetes, rosiglitazone and pioglitazone, inhibit $\beta$-secretase activity indirectly by activating nuclear peroxisome proliferator-activated receptor $\gamma$ (PPAR $\gamma)$. Both of these drugs improved cognitive and behavioral deficits in mouse models of AD (Mangialasche et al., 2010; Heneka et al., 2005; Pedersen et al., 2006). Pursuing $\beta$-secretase in the development of therapeutics has been complicated by the multitude of non-target substrates affected by the enzyme. Inhibition of $\beta$-secretase may cause toxicity due to inadvertent inhibition of proteins such as neuregulin-1, which is involved in myelination of neurons (Mangialasche et al., 2010).

Many studies have focused on developing inhibitors of $\gamma$-secretase, also involved in processing A $\beta P P$ to $A \beta$. Transgenic mice treated with $\mathrm{N}$-[N-(3,5-difluorophenacetyl)-L-alanyl]-Sphenylglycine t-butyl ester (DAPT) exhibited reduced A $\beta$ in the brain within three hours (Dovey et al., 2001). Further studies with DAPT in a different transgenic mouse model illustrated inconsistencies in cognitive outcome, with the drug reducing $A \beta$ levels in young mice and having no effect in older mice (Lanz et al., 2003). In mice and rats, semagacestat treatment lowered plasma, cerebrospinal fluid, and brain A $\beta$ levels (Henley et al., 2009). Much like the search for $\beta$-secretase inhibiting drugs, toxicity issues have plagued the development of successfully animal-tested $\gamma$-secretase inhibitors. Drugs targeting $\gamma$-secretase tend to cross-react with the Notch-1 protein, which plays an essential role in cell-fate determination (Geling et al., 2002; Micchelli et al., 2003). As a result, Notch-sparing $\gamma$-secretase inhibitors have been an attractive area of study. Begacestat lowered A $\beta$ levels and improved cognitive function in AD transgenic mice without causing Notch-related toxicity (Mayer et al., 2008).

Many in vitro and in vivo studies have demonstrated associations between neurotoxicity and $\mathrm{A} \beta$ aggregates (Cavallucci et al., 2012). A number of mechanisms have been proposed to prevent $\mathrm{A} \beta$ aggregation, or to disrupt established aggregates. 
Tramiprosate is a glycosaminoglycan (GAG) mimetic designed to fit into the GAG binding site of soluble $A \beta$, preventing aggregation (Aisen, 2005; Gervais et al., 2001). Treatment of AD transgenic mice with tramiprosate resulted in a significant reduction in $A \beta$ plaque burden (Gervais et al., 2007). MPACs bind strongly to copper and zinc, inhibiting metal-induced $A \beta$ aggregation and reactive oxygen species generation in vitro (Cherny et al., 2001). PBT2 treatment of AD transgenic mice decreased soluble brain $\mathrm{A} \beta$ within hours and improved cognitive performance within several days (Adlard et al., 2008). Scyllo-inositol also binds to $A \beta$ and is thought to regulate its folding and thereby prevent aggregation. In transgenic mice, scyllo-inositol reduced concentrations of soluble and aggregated $\mathrm{A} \beta$, plaque burden, synaptic loss, and local inflammatory responses, and improved cognitive function (McLaurin et al., 2006).

A number of immunization strategies, both active and passive, have been proposed to prevent or remove $A \beta$ deposits from the brain. Researchers have developed a number of peptides with which to immunize patients against $A \beta$ and/or $A \beta$ aggregates, postulating that antibody opsonization of the aggregates will dissolve the plaques or lead to clearance by activated microglia (Mangialasche et al., 2010). In mice, vaccination with the $A \beta$ peptide AN-1972 induced production of antibodies that prevent or remove A $\beta$ aggregates (Schenk et al., 1999; Mangialasche et al., 2010). Immunization with Cad106, a short peptide mimicking a portion of the $A \beta_{1-6}$ sequence coupled to a virus-like particle, resulted in an antibody that reduced $A \beta$ plaque in both mice and rhesus macaques (Wiessner et al., 2011). AFFITOPE technology has been utilized to develop other short (6 amino acid) peptides mimicking the N-terminus of $\mathrm{A} \beta$ without actually sharing its sequence for use in vaccines. Immunization of two different transgenic mouse lines with AFFITOPE AD-01 and $\mathrm{AD}-02$ resulted in reduced $\mathrm{A} \beta$ plaque burden and improved cognitive function (Schneeberger et al., 2009).

A number of candidate monoclonal antibody formulations, such as bapineuzumab, solanezumab and ponezumab, have been developed for passive immunization. In preclinical studies, transgenic mice were treated with monoclonal antibodies raised against $A \beta$. Vaccinated animals exhibited reduction in
$A \beta$ aggregates and synaptic pathology. Moreover, vaccinated mice experienced fewer cognitive deficits when compared with unvaccinated controls (Morgan et al., 2000; Bard et al., 2000; Buttini et al., 2005; DeMattos et al., 2001; Dodart et al., 2002).

A variety of other classes of drugs have been developed that target amelioration of AD. Latrepirdine (Dimebon) is an antihistamine that was shown to improve learning in a rat model of $\mathrm{AD}$ (Lermontova et al., 2000; Bachurin et al., 2001). Both lithium and valproate, used as mood stabilizers in the treatment of bipolar disorder, showed promising effects on $\mathrm{A} \beta$ plaque burden in AD transgenic mice (Su et al., 2004). Metrifonate, an AChEI previously used to treat schistosomiasis, showed promising increases of acetylcholine levels in rat brains, suggesting it may be successful as a treatment for AD (Mori et al., 1995).

\section{Clinical therapeutic trials for Alzheimer disease}

Despite the promising outcomes of many preclinical safety and efficacy studies, the overwhelming majority of clinical trials for potential AD treatments have failed (Tab. 2). Despite the more than 1200 clinical trials related to AD listed on http://ClinicalTrials.gov, only five drugs are currently approved for treatment of $\mathrm{AD}$. These drugs treat the symptoms of $\mathrm{AD}$ with variable effectiveness and without slowing progression of the disease (Mangialasche et al., 2010). Of the five available drugs, four are cholinesterase inhibitors. Tacrine was the first drug approved by the FDA in 1993 for the treatment of AD, though it is seldom prescribed today, as its side effects are more severe than those associated with other AChEIs. Galantamine and rivastigmine improve cognitive abilities in some patients with mild to moderate AD (Raskind et al., 2000; Wilcock et al., 2000; Kavanagh et al., 2011; Rosler et al., 1999; Farlow et al., 2000). The AChEI donepezil and the NMDA receptor antagonist memantine are the only drugs with demonstrated effectiveness in moderate to severe AD (AlzForum, 2014; Rogers and Friedhoff, 1996; Reisberg et al., 2003). Unfortunately, only about $50 \%$ of patients derive benefit from any of these drugs, and for those patients effectiveness typically is lost in six to twelve months (AlzForum, 2014).

Tab. 2: Preclinical and clinical testing results of candidate AD therapeutics as of March 2014

\begin{tabular}{|c|c|c|c|}
\hline Drug & Target & Preclinical results & Clinical trial results \\
\hline Donepezil & Cholinesterase & $\begin{array}{l}\text { Enhanced cognitive performance in mice, improved short-term } \\
\text { memory and attention deficits induced by scopolamine in rats } \\
\text { (Dawson and Iversen, 1993) }\end{array}$ & $\begin{array}{l}\text { FDA approved for all disease } \\
\text { stages (AlzForum, 2014) }\end{array}$ \\
\hline Galantamine & Cholinesterase & $\begin{array}{l}\text { Improved short-term memory and attention deficits induced } \\
\text { by scopolamine in rats, reversed cognitive deficits in mice who } \\
\text { had received CNS lesions (Sweeney et al., 1988, 1989; } \\
\text { Chopin and Briley, 1992) }\end{array}$ & $\begin{array}{l}\text { FDA approved for mild to } \\
\text { moderate AD (AlzForum, 2014) }\end{array}$ \\
\hline Rivastigmine & Cholinesterase & $\begin{array}{l}\text { Ameliorated aging-induced learning deficits and cholinergic } \\
\text { dysfunction in rats (Fisher et al., 2003) }\end{array}$ & $\begin{array}{l}\text { FDA approved for mild to } \\
\text { moderate AD (AlzForum, 2014) }\end{array}$ \\
\hline Tacrine & Cholinesterase & $\begin{array}{l}\text { Improved short-term memory and attention deficits induced by } \\
\text { scopolamine in rats (Chopin and Briley, 1992) }\end{array}$ & $\begin{array}{l}\text { FDA approved for mild to } \\
\text { moderate AD (AlzForum, 2014) }\end{array}$ \\
\hline Phenserine & Cholinesterase & $\begin{array}{l}\text { Significantly improved cognition in both rodents and canines } \\
\text { (Haroutunian et al, 1997; Patel et al., 1998; Klein, 2007) }\end{array}$ & $\begin{array}{l}\text { Not effective } \\
\text { (Becker and Greig, 2012) }\end{array}$ \\
\hline
\end{tabular}




\begin{tabular}{|c|c|c|c|}
\hline Drug & Target & Preclinical results & Clinical trial results \\
\hline Ispronicline & Cholinesterase & $\begin{array}{l}\text { Enhanced memory in mice and rats } \\
\text { (Gatto et al., 2004; Lippiello et al., 2006) }\end{array}$ & $\begin{array}{l}\text { Not effective } \\
\text { (Frolich et al., 2011) }\end{array}$ \\
\hline ABT-089 & Cholinesterase & $\begin{array}{l}\text { Improved baseline and impaired cognitive function in rats } \\
\text { (Decker et al., 1997) }\end{array}$ & Terminated $(\mathrm{NIH}, 2011)$ \\
\hline Latrepirdine & Cholinesterase & $\begin{array}{l}\text { Improved AD pathology and learning in mice and rats } \\
\text { (Lermontova et al., 2000; Perez et al., 2012; } \\
\text { Steele and Gandy, 2013) }\end{array}$ & Not effective (Neale, 2010) \\
\hline Metrifonate & Cholinesterase & Improved acetylcholine levels in rats (Mori et al., 1995) & $\begin{array}{l}\text { Withdrawn from development } \\
\text { (Lopez-Arrieta and Schneider, } \\
\text { 2006) }\end{array}$ \\
\hline EVP-6124 & Cholinesterase & Restored memory function in rats (Prickaerts et al., 2012) & In clinical trials (Hilt et al., 2012) \\
\hline Talsaclidine & $\begin{array}{l}\text { M1 muscarinic } \\
\text { receptor }\end{array}$ & $\begin{array}{l}\text { Improved cognitive outcome in mouse, rabbit, and lemur } \\
\text { models of AD (Leusch et al., 2000) }\end{array}$ & $\begin{array}{l}\text { Undesirable side effects } \\
\text { (Wienrich et al., 2001) }\end{array}$ \\
\hline AF-102B & $\begin{array}{l}\text { M1 muscarinic } \\
\text { receptor }\end{array}$ & $\begin{array}{l}\text { Improved cognitive outcome in mouse, rabbit, and lemur } \\
\text { models of AD (Fisher et al., 2003) }\end{array}$ & $\begin{array}{l}\text { Undesirable side effects } \\
\text { (AlzForum, 2014) }\end{array}$ \\
\hline AF267B & $\begin{array}{l}\text { M1 muscarinic } \\
\text { receptor }\end{array}$ & $\begin{array}{l}\text { Improved cognitive outcome in mouse, rabbit, and lemur } \\
\text { models of AD (Fisher et al., 2003; Fisher et al., 2002a) }\end{array}$ & $\begin{array}{l}\text { Undesirable side effects } \\
\text { (AlzForum, 2014) }\end{array}$ \\
\hline Memantine & NMDA receptor & Improved cognitive ability in mice (Martinez-Coria et al., 2010) & $\begin{array}{l}\text { FDA approved for moderate to } \\
\text { severe AD (Marder, 2004) }\end{array}$ \\
\hline Bis(7)-tacrine & NMDA receptor & Reduced the severity of memory deficit in rats (Liu et al., 2000) & $\mathrm{N} / \mathrm{A}$ \\
\hline Etazolate & a-secretase & Improved cognitive function in rats (Vellas et al., 2011) & $\begin{array}{l}\text { In clinical trials } \\
\text { (Vellas et al., 2011) }\end{array}$ \\
\hline Rosiglitazone & $\beta$-secretase & $\begin{array}{l}\text { Improved cognitive and behavioral deficits in mice } \\
\text { (Pedersen et al., 2006) }\end{array}$ & Not effective (Gold et al., 2010) \\
\hline Pioglitazone & $\beta$-secretase & $\begin{array}{l}\text { Improved cognitive and behavioral deficits in mice } \\
\text { (Heneka et al., 2005) }\end{array}$ & $\begin{array}{l}\text { Conflicting results } \\
\text { (Miller et al., 2011) }\end{array}$ \\
\hline LY2886721 & $\beta$-secretase & Reduced A $\beta$ load in mice (May et al., 2012) & $\begin{array}{l}\text { Trial halted: toxicity } \\
\text { (Eli Lilly, 2013b) }\end{array}$ \\
\hline DAPT & Y-secretase & $\begin{array}{l}\text { Reduced brain A } \beta \text { load within } 3 \mathrm{~h} \text { in mice } \\
\text { (Comery et al., 2005; Portelius etal., 2009) }\end{array}$ & N/A \\
\hline Semagacestat & $\mathrm{Y}$-secretase & $\begin{array}{l}\text { Lowered plasma, cerebrospinal fluid and brain } A \beta \text { levels } \\
\text { in mice and rats (Henley et al., 2009) }\end{array}$ & $\begin{array}{l}\text { Trial halted: enhanced cognitive } \\
\text { decline (Eli Lilley, 2013a) }\end{array}$ \\
\hline Begacestat & $\gamma$-secretase & $\begin{array}{l}\text { Lowered A } \beta \text { levels and improved cognitive function in mice } \\
\text { (Martone et al., 2009) }\end{array}$ & Not effective (Niva et al., 2013) \\
\hline Tarenflurbil & Y-secretase & Improves cognitive function in mice (Kukar et al., 2007) & Not effective (AlzForum, 2014) \\
\hline NIC5-15 & Y-secretase & $\begin{array}{l}\text { Improved memory and reduced } A \beta \text { burden in mice } \\
\text { (AlzForum, 2014) }\end{array}$ & $\begin{array}{l}\text { In clinical trials } \\
\text { (AlzForum, 2014) }\end{array}$ \\
\hline Avagacestat & $\mathrm{Y}$-secretase & Ameliorated cognitive deficits in mice (Mitani et al., 2012) & $\begin{array}{l}\text { Not effective } \\
\text { (Bristol-Myers Squibb, 2012) }\end{array}$ \\
\hline PBT1 & Copper/ zinc & $\begin{array}{l}\text { Decreased soluble brain } A \beta \text { within hours and improving } \\
\text { cognitive performance in mice (Adlard et al., 2008) }\end{array}$ & $\begin{array}{l}\text { Not effective } \\
\text { (Sampson et al., 2012) }\end{array}$ \\
\hline Tramiprosate & Soluble $A \beta$ & $\begin{array}{l}\text { Significant reduction in } A \beta \text { plaque burden in mice } \\
\text { (Gervais et al., 2007) }\end{array}$ & $\begin{array}{l}\text { Not effective } \\
\text { (Aisen et al., 2011) }\end{array}$ \\
\hline Scyllo-inositol & $A \beta$ & $\begin{array}{l}\text { Reduced concentrations of soluble and aggregated } A \beta \text {, } \\
\text { plaque burden, synaptic loss and local inflammatory responses, } \\
\text { and improved cognitive function in mice (Fenili et al., 2007) }\end{array}$ & $\begin{array}{l}\text { Not effective } \\
\text { (Salloway et al. 2011) }\end{array}$ \\
\hline AN-1792 & $A \beta$ immunization & $\begin{array}{l}\text { Production of antibodies that prevent or clear aggregation } \\
\text { of } A \beta \text { in mice (Schenk et al., 1999) }\end{array}$ & $\begin{array}{l}\text { Trial halted: aseptic } \\
\text { meningoencephalitis } \\
\text { (Vellas et al., 2009) }\end{array}$ \\
\hline Cad106 & $A \beta$ immunization & $\begin{array}{l}\text { Production of antibodies that reduced } A \beta \text { plaque in both mice } \\
\text { and rhesus macaques (Wiessner et al., 2011) }\end{array}$ & In clinical trials (Kingwell, 2012) \\
\hline$A D-01$ & $A \beta$ immunization & $\begin{array}{l}\text { Reduced A } \beta \text { plaque burden and improved cognitive function } \\
\text { in mice (Schneeberger et al., 2009) }\end{array}$ & $\begin{array}{l}\text { In clinical trials } \\
\text { (Panza et al., 2014) }\end{array}$ \\
\hline$A D-02$ & $A \beta$ immunization & $\begin{array}{l}\text { Reduced } A \beta \text { plaque burden and improved cognitive function } \\
\text { in mice (Schneeberger et al., 2009) }\end{array}$ & $\begin{array}{l}\text { In clinical trials } \\
\text { (Panza et al., 2014) }\end{array}$ \\
\hline
\end{tabular}




\begin{tabular}{|c|c|c|c|}
\hline Drug & Target & Preclinical results & Clinical trial results \\
\hline Bapineuzumab & $A \beta$ antibody & $\begin{array}{l}\text { Reduction in A } \mathrm{A} \text { aggregates and synaptic pathology, fewer } \\
\text { cognitive deficits in mice (Bard et al., 2012) }\end{array}$ & $\begin{array}{l}\text { Not effective } \\
\text { (Salloway et al., 2009) }\end{array}$ \\
\hline Solanezumab & $A \beta$ antibody & $\begin{array}{l}\text { Reduction in A } \beta \text { aggregates and synaptic pathology, fewer } \\
\text { cognitive deficits in mice (Imbimbo et al., 2012) }\end{array}$ & $\begin{array}{l}\text { Not effective } \\
\text { (Doody et al., 2014) }\end{array}$ \\
\hline Ponezumab & $A \beta$ antibody & $\begin{array}{l}\text { Reduction in } A \beta \text { aggregates and synaptic pathology, fewer } \\
\text { cognitive deficits in mice (La Porte et al., 2012) }\end{array}$ & Not effective (AlzForum, 2014) \\
\hline Gammagard & $A \beta$ antibody & $\begin{array}{l}\text { Reduced } A \beta \text { deposition, modulated inflammatory response } \\
\text { in mice (Sudduth et al., 2013) }\end{array}$ & Not effective (AlzForum, 2014) \\
\hline MABT-5102A & $A \beta$ antibody & $\begin{array}{l}\text { Reduced } A \beta \text { load and inflammation in mice } \\
\text { (Adolfsson et al., 2012) }\end{array}$ & In clinical trials $(\mathrm{NIH}, 2013 \mathrm{c})$ \\
\hline
\end{tabular}

Among AChEIs, phenserine, ispronicline and ABT-089 have been tested in patients with $\mathrm{AD}$, but resulted in no significant change in cognitive function (Klein, 2007; Becker and Greig, 2012; NIH, 2011). Talsaclidine, AF-102B, and AF-267B resulted in undesirable side effects, such as increased salivation, and are no longer being developed for treatment of AD (Mangialasche et al., 2010; Hock et al., 2003; Heinrich et al., 2009). Similarly, the $\beta$-secretase inhibitors LY2886721 and rosiglitazone, and $\gamma$-secretase inhibitors avagacestat and tarenflurbil entered clinical trials and resulted in either no improvement in cognitive function in AD patients or, in the case of LY2886721, toxicity to those receiving the drug (Green et al., 2009; Imbimbo and Giardina, 2011; Bristol-Myers Squibb, 2012; Eli Lilly and Company, 2013b). Semagacestat development was halted when it led to worsening of AD symptoms (Eli Lilly and Company, 2013a; Samson, 2010; Extance, 2010). Drugs designed to prevent or eliminate aggregation of $\mathrm{A} \beta$, tramiprosate and scyllo-inositol, produced no improvement in cognitive function. Scyllo-inositol is currently being studied as a possible treatment for aggression in AD patients (Aisen et al., 2011; Salloway et al., 2011; NIH, 2013a). MPAC PBT1 failed to improve cognitive outcome in patients with $\mathrm{AD}$ and was withdrawn from development, though PBT2 remains in clinical trials (Sampson et al., 2012).

Recently, promising results from animal studies of active or passive immunotherapy for AD have garnered enthusiasm for subsequent clinical trials. Clinical trials with AN-1792, the first active immunization against $A \beta$, were halted when a number of patients developed aseptic meningoencephalitis (Orgogozo et al., 2003). Trials with passive immunotherapy candidates bapineuzumab, PF-04360365, and IVIg (Gammagard), have failed to slow disease progression or improve cognition in $\mathrm{AD}$ patients (Baxter InternationalInc, 2013; Salloway et al., 2009; Dodel et al., 2013; Pfizer, 2011). Solanezumab was not effective in patients with moderately severe $\mathrm{AD}$, and its effect on mild AD is currently being studied (Tayeb et al., 2013; Imbimbo et al., 2012).

Despite the high failure rate for clinical trials of AD drugs and the limited benefits of approved drugs, a number of candidate therapeutics remain in the pipeline. EVP-6124, a nicotinic receptor agonist, showed sufficient cognitive benefits in a sixmonth phase II trial of 409 subjects to be advanced to a phase III trial (Hilt, 2012). NIC5-15, a Notch-sparing $\gamma$-secretase inhibitor, was well tolerated in phase I trials and is currently undergo- ing phase II testing (Pharmeceuticals, 2006). The $\alpha$-secretase activator etazolate was well-tolerated in phase I trials. A phase II trial with etazolate showed promising outcomes on AD patient cognition, and the drug is under further development (Vellas et al., 2011). Green tea extract epigallocatechin gallate (ECGC), also an inhibitor of $A \beta$ aggregation, recently entered phase II/III trials (Zhang et al., 2013a; Smid et al., 2012; NIH, 2013b).

Although development of immunotherapy strategies to treat $\mathrm{AD}$ has been disappointing, two candidate therapeutics are currently in phase II trials. AD02, a vaccine against $\mathrm{A} \beta$, was safe and stabilized cognition in AD patients (NIH, 2012, 2010). MABT$5102 \mathrm{~A}$, a humanized monoclonal antibody directed against $\mathrm{A} \beta$, exhibited a favorable safety profile in phase I testing (Adolfsson et al., 2012; NIH, 2013c). However, the consistent history of late-stage failures of $\mathrm{AD}$ drugs suggests that promising phase I and II trials are not predictive for phase III success. Failures have been related both to inefficacy and toxicities, emphasizing the limitations in predictability of animal models for AD drug testing, and adding to the evidence that $\mathrm{AD}$ drug development and testing should be reformed.

\section{Modifiable lifestyle factors in AD}

While the development of pharmaceuticals is an important venture, other areas of research have focused on the effects of nutritional supplements and modifiable lifestyle factors on AD. Identifying nutritional factors and lifestyle modifications that prevent, delay, or attenuate $\mathrm{AD}$ symptoms would be beneficial to patients, as these approaches are inexpensive and typically associated with beneficial rather than adverse side effects. Over the course of the last decade, researchers have begun to explore modifiable risk factors with prevention in mind, and a number of studies in this area have yielded promising results.

Much of the AD prevention data currently available suggest a link between cardiovascular disease and the development of AD or other dementias (Mayo Clinic, 2013; Honjo et al., 2012; Duke Medical News, 2013; Roberts et al., 2013). A study of adults possessing at least one ApoE4 allele revealed that hypertensive individuals tended to have significantly higher $\mathrm{A} \beta$ burdens than those with normal blood pressure (Rodrigue et al., 2013). Moreover, cholesterol is involved in generation and deposition of $A \beta$ in the brain, though cholesterol modification 
has not yet been shown to ameliorate AD symptoms (Puglielli et al., 2003; Roberts et al., 2013; Feldman et al., 2010). Lifestyle factors such as dietary composition and physical activity, which have a positive effect on cardiovascular health, may also aid in preventing AD (Roberts et al., 2013; Mayo Clinic, 2013).

The Chicago Health and Aging Project (CHAP) is " $a$ longitudinal population study of common chronic health problems of older persons, especially of risk factors for incident Alzheimer's disease, in a biracial neighborhood of the south side of Chicago"(Bienias et al., 2003). This study has identified saturated fat and trans-unsaturated fat as positive correlates with development of $\mathrm{AD}$, while omega- 6 polyunsaturated fat and monounsaturated fat were associated with a decreased risk of AD (Morris et al., 2003). A similar study in New York revealed comparable correlations between high intake of calories, cholesterol, and saturated fat and the development of dementia (Luchsinger et al., 2002). Although treatment of AD with statins has not been successful, use of statins earlier in life is associated with decreased risk of $\mathrm{AD}$, suggesting that potential benefits of statins may be limited to prevention (Feldman et al., 2010; Cramer et al., 2008; Haag et al., 2009). Similarly, a Finnish study revealed a link between high serum cholesterol and elevated risk of $\mathrm{AD}$ later in life, suggesting again that lower cholesterol may decrease AD risk (Notkola et al., 1998).

Long-chain omega-3 fatty acids, a type of polyunsaturated fat, may play a role in prevention of AD. Docosahexaenoic acid (DHA) is the principal omega-3 fatty acid component of neuronal membranes (Cunnane et al., 2012). DHA is especially abundant in areas of the brain such as the cerebral cortex, synaptosomes, and mitochondria. Neurons do not possess the enzymes necessary for de novo synthesis of DHA, so it must either be obtained directly from the diet or synthesized endogenously from its precursors $\alpha$-linolenic acid and eicosapentaenoic acid (Cunnane et al., 2012; Salem et al., 1996). In a number of epidemiological studies in the US and Europe, consumption of omega-3 fatty acids and fish at least once a week was associated with decreased incidences of AD and general cognitive decline (Morris et al., 2003; Schaefer et al., 2006; van Gelder et al., 2007; Barberger-Gateau et al., 2007).

The antioxidant properties of vitamins $\mathrm{E}$ and $\mathrm{C}$ are of interest in the $\mathrm{AD}$ field, as oxidative stress in CNS neurons disrupts normal cellular function and contributes to AD pathology (Morris et al., 2002; Gutteridge, 1994; Simonian and Coyle, 1996; Smith and Perry, 1995; Sopher et al., 1996). A number of studies have been carried out regarding the effect of vitamins $\mathrm{E}$ and $\mathrm{C}$ on preventing $\mathrm{AD}$, but with conflicting results. In CHAP and the Rotterdam Study, vitamin E intake was associated with decreased risk of AD (Morris et al., 2002; Engelhart et al., 2002). Results from the Rotterdam study also suggest a role for vitamin $\mathrm{C}$ in AD prevention (Engelhart et al., 2002). However, a study regarding both vitamin $\mathrm{E}$ and $\mathrm{C}$ intake in New York revealed no correlation between antioxidant supplementation and decreased incidence of $\mathrm{AD}$, and other studies investigating the effects of omega-3 fatty acids and antioxidants on established AD have shown no benefit (Freund-Levi et al., 2009; Luchsinger et al., 2003; Isaac et al., 2008).
The link between cardiovascular health and AD risk extends beyond dietary factors to incorporate physical activity levels as well. A number of promising studies report that physical activity slows cognitive decline in the elderly, with or without a diagnosis of AD (Weuve et al., 2004; Pitkala et al., 2013). Moreover, individuals who engage in physical activity at mid-life appear to be less susceptible to AD (Rovio et al., 2005; Podewils et al., 2005; Scarmeas et al., 2009; Larson et al., 2006; Middleton et al., 2008; de Bruijn et al., 2013). While the mechanisms underlying the effect of exercise on cognition require more study, there is evidence to suggest that physical activity improves brain plasticity, and may lead to increases in prefrontal and hippocampal volume (Erickson et al., 2012; Radak et al., 2010). The association between exercise and reduced risk of AD may be more pronounced in individuals carrying the ApoE4 allele, though this association requires more study (Rovio et al., 2005; Podewils et al., 2005; Pizzie et al., 2013). Promisingly, a recent study suggested that exercise may improve cognitive ability and semantic memory retrieval in patients already diagnosed with mild cognitive impairment (Smith et al., 2013).

Overall, a strong argument can be made for the role of diet and physical activity in $\mathrm{AD}$ prevention. Altogether, the results of the cited studies suggest a diet of foods such as nuts, cruciferous vegetables, fruit, and dark, leafy vegetables may put individuals at a lower risk for developing AD later in life. Avoiding foods high in saturated and trans-unsaturated fats, such as red meat, butter, and dairy products will contribute to a lower risk of AD. Moreover, regular physical activity may independently lower the risk of developing dementia (Wilbur et al., 2012).

\section{The path forward: humanizing AD research}

Although animal models used to investigate AD have largely failed to yield mechanistic or treatment insights that conclusively correlate with human AD pathology or predict the safety and efficacy of therapeutic drugs, gaining an understanding of the mechanisms underlying $\mathrm{AD}$ pathology remains essential. In this review, we have detailed the ways in which current animal models of $\mathrm{AD}$ fail to accurately reflect the disease as it occurs in humans. Rather than continuing to use existing models or attempting to create new transgenic lines, evidence indicates that we should move away from animal models. Researchers should take advantage of postmortem studies, human patient samples, and tissue biobanks. Moreover, advances in induced pluripotent stem cell technology show great promise for neurodegenerative disease research (Almeida et al., 2013; Boissart et al., 2013; Burkhardt et al., 2013; Ieda, 2013; Zhang et al., 2013b). These basic science resources, combined with epidemiological studies, observational research with $\mathrm{AD}$ patients, and clinical trials, will allow researchers to have access to results that are directly relevant to $\mathrm{AD}$ in the species of interest.

Biomarker validation has become a hot research topic in the AD field. Transcriptomics, such as DNA/mRNA microarrays, has led to identification of a few genes whose expression is altered in $\mathrm{AD}$, but this technology alone has not proven sensitive enough for broad biomarker detection (Humpel, 2011). 
Recently, there has been enthusiasm for a combined genetic and proteomic approach (Thambisetty and Lovestone, 2010; Humpel, 2011). The ideal biomarkers will be stable, present in easily accessible patient samples (blood, CSF), with notable differences between age-matched healthy controls and individuals with AD (Humpel, 2011; Verwey et al., 2009; Lewczuk et al., 2008). Standardized diagnostics will increase the accuracy with which biomarker validation is performed.

Ideally, research funds will be directed toward validating biomarkers and optimizing rapid, accurate biomarker detection methods. Development of patient-specific DNA, RNA and proteomic chips able to detect multiple biomarkers simultaneously is of great interest (Humpel, 2011). Expanded use of Pittsburgh Compound Blue positron emission tomography to detect and track amyloid deposition in the brain may enhance the search for viable biomarkers of AD. Recent research indicates that spatial distribution of amyloid deposits, rather than total amyloid burden, correlates well with cognitive decline (Yotter et al., 2013). Use of this in combination with cognitive outcome will allow researchers to more accurately track the progression of mild cognitive impairment to AD. Despite the availability of blood and CSF samples from patients, some researchers insist on validating biomarkers in the aforementioned animal models (Rose et al., 2012; Spencer et al., 2013; Tai et al., 2013). Restricting biomarker research to human samples may produce viable candidates while eliminating unreliable interpretation of data that may occur when translating results from animals to humans. Together, these approaches will enhance the ability of researchers to evaluate the efficacy of preventive strategies or biomarker correlates.

Finally, reinforcing clinical trial education for both patients and physicians may increase the number of individuals willing to enroll in clinical trials. In recent years, pharmaceutical and device companies have moved many operations overseas (Garnier, 2008). Among NIH-funded studies, insufficient domestic enrollment has forced investigators to seek participants internationally (Kim et al., 2011; Eapen et al., 2013). While this is, to some degree, the result of the expense and complex regulations governing clinical studies in the US, physician involvement in clinical studies plays a role as well. Results from a Research American poll indicated that $75 \%$ of potential participants surveyed would be interested in participating in a clinical trial (Charlton Research Company, 2009). Medical school and residency training programs can be enhanced by requiring physicians in training to learn both why and how to enroll patients in clinical trials (Eapen et al., 2013). Moreover, outreach and education to the American public regarding the importance of clinical trial participation and what trials may be available to them will only serve to improve the quality of US trials and their applicability to US patients (Eapen et al., 2013).

\section{Conclusions}

The U.S. Department of Health and Human Services recently updated the National Plan to Address Alzheimer's Disease. This update calls for increased enrollment in clinical trials and expanded research to identify biomarkers, genetic risk factors, and pharmaceutical and lifestyle interventions. The inclusion of studies on the roles of lifestyle factors in the prevention or treatment of $\mathrm{AD}$ is laudable. However, despite making lifestyle intervention research a priority, only a small fraction of NIH research dollars allocated to AD studies go to researchers studying nutrition, physical activity, or models of dementia care. With the overwhelming failure of drug trials in recent years, it is imperative that we shift our focus and cash flow to these prevention and intervention studies, affording them the same importance we place on biomarker and risk factor research. Moreover, increasing our investment in basic science research that takes advantage of human-based technologies, such as inducible pluripotent stem cells, improves the likelihood of discoveries that are applicable to human disease.

Alzheimer disease exacts a physically, emotionally, and financially devastating toll on those affected by it. With the incidence of AD expected to triple in the next several decades, it is more important than ever that preventive measures and successful treatments be established. Current basic research strategies involving animal models of $\mathrm{AD}$ have been unable to achieve these goals due to unreliability and poor translation to human $\mathrm{AD}$. By removing the emphasis of $\mathrm{AD}$ research from animal models and placing it on the human patient, we can expect to increase the likelihood of identifying methods by which AD may be prevented, ameliorated, and reversed.

\section{References}

Adlard, P. A., Cherny, R. A., Finkelstein, D. I. et al. (2008). Rapid restoration of cognition in Alzheimer's transgenic mice with 8-hydroxy quinoline analogs is associated with decreased interstitial Abeta. Neuron 59, 43-55. http://dx.doi.org/10.1016/ j.neuron.2008.06.018

Adolfsson, O., Pihlgren, M., Toni, N. et al. (2012). An effectorreduced anti-beta-amyloid (Abeta) antibody with unique abeta binding properties promotes neuroprotection and glial engulfment of Abeta. J Neurosci 32, 9677-9689. http://dx.doi. org/10.1523/JNEUROSCI.4742-11.2012

Aisen, P. S. (2005). The development of anti-amyloid therapy for Alzheimer's disease: From secretase modulators to polymerisation inhibitors. CNS Drugs 19, 989-996.

Aisen, P. S., Gauthier, S., Ferris, S. H. et al. (2011). Tramiprosate in mild-to-moderate Alzheimer's disease - a randomized, double-blind, placebo-controlled, multi-centre study (the Alphase Study). Arch Med Sci 7, 102-111. http://dx.doi.org/10.5114/ aoms.2011.20612

Akiyama, H., Barger, S., Barnum, S. et al. (2000). Inflammation and Alzheimer's disease. Neurobiol Aging 21,383-421.

Allen, B., Ingram, E., Takao, M. et al. (2002). Abundant tau filaments and nonapoptotic neurodegeneration in transgenic mice expressing human P301S tau protein. J Neurosci 22, 93409351.

Almeida, S., Gascon, E., Tran, H. et al. (2013). Modeling key pathological features of frontotemporal dementia with C9ORF72 repeat expansion in iPSC-derived human neurons. Acta Neuropathol 126, 385-399. http://dx.doi.org/10.1007/s00401-0131149-y 
AlzForum (2014). Drugs and Therapies. http://www.alzforum. org/therapeutics

Alzheimer's Association (2013). 2013 Alzheimer's Disease Facts and Figures. http://www.alz.org/alzheimers_disease_facts_ and_figures.asp

Alzheimer's Disease International (2009). World Alzheimer Report 2009. http://www.alz.co.uk/research/files/WorldAlz heimerReport.pdf

Andorfer, C., Kress, Y., Espinoza, M. et al. (2003). Hyperphosphorylation and aggregation of tau in mice expressing normal human tau isoforms. $J$ Neurochem $86,582-590$.

Bachurin, S., Bukatina, E., Lermontova, N. et al. (2001). Antihistamine agent Dimebon as a novel neuroprotector and a cognition enhancer. Ann N Y Acad Sci 939, 425-435.

Barberger-Gateau, P., Raffaitin, C., Letenneur, L. et al. (2007). Dietary patterns and risk of dementia: The Three-City cohort study. Neurology 69, 1921-1930. http://dx.doi.org/10.1212/01. wnl.0000278116.37320.52

Bard, F., Cannon, C., Barbour, R. et al. (2000). Peripherally administered antibodies against amyloid beta-peptide enter the central nervous system and reduce pathology in a mouse model of Alzheimer disease. Nat Med 6, 916-919. http://dx.doi. org/10.1038/78682

Bard, F., Fox, M., Friedrich, S. et al. (2012). Sustained levels of antibodies against Abeta in amyloid-rich regions of the CNS following intravenous dosing in human APP transgenic mice. Exp Neurol 238, 38-43. http://dx.doi.org/10.1016/j. expneurol.2012.07.022

Barnes, C. A., Danysz, W. and Parsons, C. G. (1996). Effects of the uncompetitive NMDA receptor antagonist memantine on hippocampal long-term potentiation, short-term exploratory modulation and spatial memory in awake, freely moving rats. Eur J Neurosci 8, 565-571.

Baxter International, Inc. (2013). Baxter announces topline results of phase III study of immunoglobulin for Alzheimer's disease. http://www.baxter.com/press_room/press_releases/ 2013/05_07_13_gap_study.html

Becker, R. E. and Greig, N. H. (2012). Was phenserine a failure or were investigators mislead by methods? Curr Alzheimer Res 9, 1174-1181.

Benzing, W. C., Wujek, J. R., Ward, E. K. et al. (1999). Evidence for glial-mediated inflammation in aged APP(SW) transgenic mice. Neurobiol Aging 20, 581-589.

Bienias, J. L., Beckett, L. A., Bennett, D. A. et al. (2003). Design of the Chicago Health and Aging Project (CHAP). J Alzheimers Dis 5, 349-355.

Bierer, L. M., Hof, P. R., Purohit, D. P. et al. (1995). Neocortical neurofibrillary tangles correlate with dementia severity in Alzheimer's disease. Arch Neurol 52, 81-88.

Blanchard, V., Czech, C., Bonici, B. et al. (1997). Immunohistochemical analysis of presenilin 2 expression in the mouse brain: Distribution pattern and co-localization with presenilin 1 protein. Brain Res 758, 209-217.

Blanchard, V., Moussaoui, S., Czech, C. et al. (2003). Time sequence of maturation of dystrophic neurites associated with Abeta deposits in APP/PS1 transgenic mice. Exp Neurol 184, 247-263.
Bodendorf, U., Danner, S., Fischer, F. et al. (2002). Expression of human beta-secretase in the mouse brain increases the steadystate level of beta-amyloid. J Neurochem 80, 799-806.

Boissart, C., Poulet, A., Georges, P. et al. (2013). Differentiation from human pluripotent stem cells of cortical neurons of the superficial layers amenable to psychiatric disease modeling and high-throughput drug screening. Transl Psychiatry 3, e294. http://dx.doi.org/10.1038/tp.2013.71

Bons, N., Rieger, F., Prudhomme, D. et al. (2006). Microcebus murinus: A useful primate model for human cerebral aging and Alzheimer's disease? Genes Brain Behav 5, 120-130. http:// dx.doi.org/10.1111/j.1601-183X.2005.00149.x

Borchelt, D. R., Ratovitski, T., van Lare, J. et al. (1997). Accelerated amyloid deposition in the brains of transgenic mice coexpressing mutant presenilin 1 and amyloid precursor proteins. Neuron 19, 939-945.

Bores, G. M., Huger, F. P., Petko, W. et al. (1996). Pharmacological evaluation of novel Alzheimer's disease therapeutics: Acetylcholinesterase inhibitors related to galanthamine. J Pharmacol Exp Ther 277, 728-738.

Brion, J. P., Tremp, G. and Octave, J. N. (1999). Transgenic expression of the shortest human tau affects its compartmentalization and its phosphorylation as in the pretangle stage of Alzheimer's disease. Am J Pathol 154, 255-270. http://dx.doi. org/10.1016/S0002-9440(10)65272-8

Bristol-Myers Squibb (2012). Statement on Avagacestat development status. http://www.bms.com/news/features/2012/Pages/ AvagacestatDevelopmentStatus.aspx

Burkhardt, M. F., Martinez, F. J., Wright, S. et al. (2013). A cellular model for sporadic ALS using patient-derived induced pluripotent stem cells. Mol Cell Neurosci 56C, 355-364. http:// dx.doi.org/10.1016/j.mcn.2013.07.007

Buttini, M., Masliah, E., Barbour, R. et al. (2005). Beta-amyloid immunotherapy prevents synaptic degeneration in a mouse model of Alzheimer's disease. J Neurosci 25, 9096-9101. http:// dx.doi.org/10.1523/JNEUROSCI.1697-05.2005

Cai, H., Wang, Y., McCarthy, D. et al. (2001). BACE1 is the major beta-secretase for generation of Abeta peptides by neurons. Nat Neurosci 4, 233-234. http://dx.doi.org/10.1038/85064

Calhoun, M. E., Wiederhold, K. H., Abramowski, D. et al. (1998). Neuron loss in APP transgenic mice. Nature 395, 755-756. http://dx.doi.org/10.1038/27351

Casas, C., Sergeant, N., Itier, J. M. et al. (2004). Massive CA1/2 neuronal loss with intraneuronal and $\mathrm{N}$-terminal truncated Abeta42 accumulation in a novel Alzheimer transgenic model. Am J Pathol 165, 1289-1300.

Cavallucci, V., D'Amelio, M. and Cecconi, F. (2012). Abeta toxicity in Alzheimer's disease. Mol Neurobiol 45, 366-378. http:// dx.doi.org/10.1007/s12035-012-8251-3

Chai, C. K. (2007). The genetics of Alzheimer's disease. Am J Alzheimers Dis Other Demen 22, 37-41.

Chan, A. W. and Yang, S. H. (2009). Generation of transgenic monkeys with human inherited genetic disease. Methods 49, 78-84. http://dx.doi.org/10.1016/j.ymeth.2009.05.007

Chapman, P. F., White, G. L., Jones, M. W. et al. (1999). Impaired synaptic plasticity and learning in aged amyloid precursor protein transgenic mice. Nat Neurosci 2, 271-276. http://dx.doi. 
org/10.1038/6374

Charlton Research Company (2009). America speaks: Poll data summary, volume 10. http://www.researchamerica.org/uploads/ AmericaSpeaks V10.pdf

Chartier-Harlin, M. C., Crawford, F., Houlden, H. et al. (1991). Early-onset Alzheimer's disease caused by mutations at codon 717 of the beta-amyloid precursor protein gene. Nature 353, 844-846. http://dx.doi.org/10.1038/353844a0

Chen, Y., Niu, Y. and Ji, W. (2012). Transgenic nonhuman primate models for human diseases: Approaches and contributing factors. J Genet Genomics 39, 247-251. http://dx.doi.org/10.1016/ j.jgg.2012.04.007

Cheng, I. H., Palop, J. J., Esposito, L. A. et al. (2004). Aggressive amyloidosis in mice expressing human amyloid peptides with the Arctic mutation. Nat Med 10, 1190-1192. http://dx.doi. org/10.1038/nm1123

Cheng, I. H., Scearce-Levie, K., Legleiter, J. et al. (2007). Accelerating amyloid-beta fibrillization reduces oligomer levels and functional deficits in Alzheimer disease mouse models. $J$ Biol Chem 282, 23818-23828. http://dx.doi.org/10.1074/jbc. M701078200

Cherny, R. A., Atwood, C. S., Xilinas, M. E. et al. (2001). Treatment with a copper-zinc chelator markedly and rapidly inhibits beta-amyloid accumulation in Alzheimer's disease transgenic mice. Neuron 30, 665-676.

Chin, J., Palop, J. J., Puolivali, J. et al. (2005). Fyn kinase induces synaptic and cognitive impairments in a transgenic mouse model of Alzheimer's disease. J Neurosci 25, 9694-9703. http:// dx.doi.org/10.1523/JNEUROSCI.2980-05.2005

Chishti, M. A., Yang, D. S., Janus, C. et al. (2001). Early-onset amyloid deposition and cognitive deficits in transgenic mice expressing a double mutant form of amyloid precursor protein 695. J Biol Chem 276, 21562-21570. http://dx.doi.org/10.1074/ jbc.M100710200

Chopin, P. and Briley, M. (1992). Effects of four non-cholinergic cognitive enhancers in comparison with tacrine and galanthamine on scopolamine-induced amnesia in rats. Psychopharmacology (Berl) 106, 26-30.

Cohen, R. M., Rezai-Zadeh, K., Weitz, T. M. et al. (2013). A transgenic Alzheimer rat with plaques, tau pathology, behavioral impairment, oligomeric abeta, and Frank neuronal loss. J Neurosci 33, 6245-6256. http://dx.doi.org/10.1523/JNEURO SCI.3672-12.2013

Colle, M. A., Hauw, J. J., Crespeau, F. et al. (2000). Vascular and parenchymal Abeta deposition in the aging dog: Correlation with behavior. Neurobiol Aging 21, 695-704.

Comery, T. A., Martone, R. L., Aschmies, S. et al. (2005). Acute gamma-secretase inhibition improves contextual fear conditioning in the $\operatorname{Tg} 2576$ mouse model of Alzheimer's disease. J Neurosci 25, 8898-8902. http://dx.doi.org/10.1523/JNEURO SCI.2693-05.2005

Corder, E. H., Saunders, A. M., Strittmatter, W. J.et al. (1993). Gene dose of apolipoprotein E type 4 allele and the risk of Alzheimer's disease in late onset families. Science 261, 921-923.

Cotman, C. W. and Head, E. (2008). The canine (dog) model of human aging and disease: Dietary, environmental and immunotherapy approaches. J Alzheimers Dis 15, 685-707.
Cramer, C., Haan, M. N., Galea, S. et al. (2008). Use of statins and incidence of dementia and cognitive impairment without dementia in a cohort study. Neurology 71,344-350. http://dx.doi. org/10.1212/01.wnl.0000319647.15752.7b

Cuijpers, P. (2005). Depressive disorders in caregivers of dementia patients: A systematic review. Aging Ment Health 9, 325330. http://dx.doi.org/10.1080/13607860500090078

Cummings, B. J., Head, E., Afagh, A. J. et al. (1996a). Betaamyloid accumulation correlates with cognitive dysfunction in the aged canine. Neurobiol Learn Mem 66, 11-23. http://dx.doi. org/10.1006/nlme.1996.0039

Cummings, B. J., Head, E., Ruehl, W. et al. (1996b). The canine as an animal model of human aging and dementia. Neurobiol Aging 17, 259-268.

Cunnane, S. C., Schneider, J. A., Tangney, C. et al. (2012). Plasma and brain fatty acid profiles in mild cognitive impairment and Alzheimer's disease. J Alzheimers Dis 29, 691-697. http:// dx.doi.org/10.3233/JAD-2012-110629

Danysz, W. and Parsons, C. G. (2003). The NMDA receptor antagonist memantine as a symptomatological and neuroprotective treatment for Alzheimer's disease: Preclinical evidence. Int J Geriatr Psychiatry 18, S23-32. http://dx.doi.org/10.1002/ gps.938

Davis, J., Maillet, M., Miano, J. M. et al. (2012). Lost in transgenesis: A user's guide for genetically manipulating the mouse in cardiac research. Circ Res 111, 761-777. http://dx.doi. org/10.1161/CIRCRESAHA.111.262717

Dawson, G. R. and Iversen, S. D. (1993). The effects of novel cholinesterase inhibitors and selective muscarinic receptor agonists in tests of reference and working memory. Behav Brain Res 57, 143-153.

de Bruijn, R. F., Schrijvers, E. M., de Groot, K. A. et al. (2013). The association between physical activity and dementia in an elderly population: The Rotterdam Study. Eur J Epidemiol 28, 277-283. http://dx.doi.org/10.1007/s10654-013-9773-3

de la Monte, S. M. and Wands, J. R. (2005). Review of insulin and insulin-like growth factor expression, signaling, and malfunction in the central nervous system: Relevance to Alzheimer's disease. J Alzheimers Dis 7, 45-61.

de Vugt, M. E., Stevens, F., Aalten, P. et al. (2005). A prospective study of the effects of behavioral symptoms on the institutionalization of patients with dementia. Int Psychogeriatr 17, 577 589. http://dx.doi.org/10.1017/S1041610205002292

Decker, M. W., Bannon, A. W., Curzon, P. et al. (1997). ABT-089 [2-methyl-3-(2-(S)-pyrrolidinylmethoxy)pyridine dihydrochloride]: II. A novel cholinergic channel modulator with effects on cognitive performance in rats and monkeys. $J$ Pharmacol Exp Ther 283, 247-258.

Del Valle, J., Duran-Vilaregut, J., Manich, G. et al. (2010). Early amyloid accumulation in the hippocampus of SAMP8 mice. J Alzheimers Dis 19, 1303-1315. http://dx.doi.org/10.3233/ JAD-2010-1321

DeMattos, R. B., Bales, K. R., Cummins, D. J. et al. (2001). Peripheral anti-A beta antibody alters CNS and plasma A beta clearance and decreases brain A beta burden in a mouse model of Alzheimer's disease. Proc Natl Acad Sci U S A 98, 88508855. http://dx.doi.org/10.1073/pnas.151261398 
Dickson, D. W., Crystal, H. A., Bevona, C. et al. (1995). Correlations of synaptic and pathological markers with cognition of the elderly. Neurobiol Aging 16, 285-298; discussion 298-304.

Dodart, J. C., Mathis, C., Saura, J. et al. (2000). Neuroanatomical abnormalities in behaviorally characterized APP $(\mathrm{V} 717 \mathrm{~F})$ transgenic mice. Neurobiol Dis 7, 71-85. http://dx.doi.org/10.1006/ nbdi.1999.0278

Dodart, J. C., Bales, K. R., Gannon, K. S. et al. (2002). Immunization reverses memory deficits without reducing brain Abeta burden in Alzheimer's disease model. Nat Neurosci 5, 452-457. http://dx.doi.org/10.1038/nn842

Dodel, R., Rominger, A., Bartenstein, P. et al. (2013). Intravenous immunoglobulin for treatment of mild-to-moderate Alzheimer's disease: A phase 2, randomised, double-blind, placebo-controlled, dose-finding trial. Lancet Neurol 12, 233-243. http://dx.doi. org/10.1016/S1474-4422(13)70014-0

Doody, R. S., Thomas, R. G., Farlow, M. et al. (2014). Phase 3 trials of solanezumab for mild-to-moderate Alzheimer's disease. $N$ Engl J Med 370, 311-321. http://dx.doi.org/10.1056/ NEJMoa1312889

Dovey, H. F., John, V., Anderson, J. P. et al. (2001). Functional gamma-secretase inhibitors reduce beta-amyloid peptide levels in brain. $J$ Neurochem 76, 173-181.

Duff, K., Eckman, C., Zehr, C. et al. (1996). Increased amyloidbeta42(43) in brains of mice expressing mutant presenilin 1 . Nature 383, 710-713. http://dx.doi.org/10.1038/383710a0

Duff, K., Knight, H., Refolo, L. M. et al. (2000). Characterization of pathology in transgenic mice over-expressing human genomic and cDNA tau transgenes. Neurobiol Dis 7,87-98. http:// dx.doi.org/10.1006/nbdi.1999.0279

Duke Medical News(2013). Enocuraging news in Alzheimer's prevention and treatment. Research continues to underscore the value of cardiovascular health in relation to brain function. Duke Med Health News 19, 4-5.

Duyckaerts, C., Potier, M. C. and Delatour, B. (2008). Alzheimer disease models and human neuropathology: Similarities and differences. Acta Neuropathol 115, 5-38. http://dx.doi. org/10.1007/s00401-007-0312-8

Eapen, Z. J., Vavalle, J. P., Granger, C. B. et al. (2013). Rescuing clinical trials in the United States and beyond: A call for action. Am Heart J 165, 837-847. http://dx.doi.org/10.1016/ j.ahj.2013.02.003

Eikelenboom, P. and Stam, F. C. (1982). Immunoglobulins and complement factors in senile plaques. An immunoperoxidase study. Acta Neuropathol 57, 239-242.

Eikelenboom, P., Hack, C. E., Rozemuller, J. M. et al. (1989). Complement activation in amyloid plaques in Alzheimer's dementia. Virchows Arch B Cell Pathol Incl Mol Pathol 56, 259262.

Eikelenboom, P. and Veerhuis, R. (1996). The role of complement and activated microglia in the pathogenesis of Alzheimer's disease. Neurobiol Aging 17,673-680.

Eli Lilly and Company (2013a). Lilly Halts development of Semagacestat for Alzheimer's disease based on preliminary results of phase III clinical trials. http://newsroom.lilly.com/ releasedetail.cfm?releaseid $=499794$

Eli Lilly and Company (2013b). Lilly voluntarily terminates phase
II study for LY2886721, a beta secretase inhibitor, being investigated as a treatment for Alzheimer's disease. https://investor. lilly.com/releasedetail.cfm?ReleaseID=771353

Engelhart, M. J., Geerlings, M. I., Ruitenberg, A. et al. (2002). Dietary intake of antioxidants and risk of Alzheimer disease. JAMA 287, 3223-3229.

Erickson, K. I., Weinstein, A. M. and Lopez, O. L. (2012). Physical activity, brain plasticity, and Alzheimer's disease. Arch Med Res 43, 615-621. http://dx.doi.org/10.1016/j.arcmed.2012.09.008

Extance, A. (2010). Alzheimer's failure raises questions about disease-modifying strategies. Nat Rev Drug Discov 9, 749-751. http://dx.doi.org/10.1038/nrd3288

Farlow, M., Anand, R., Messina, J., Jr. et al. (2000). A 52-week study of the efficacy of rivastigmine in patients with mild to moderately severe Alzheimer's disease. Eur Neurol 44, 236241. http://dx.doi.org/8243

Feldman, H. H., Doody, R. S., Kivipelto, M. et al. (2010). Randomized controlled trial of atorvastatin in mild to moderate Alzheimer disease: LEADe. Neurology 74, 956-964. http:// dx.doi.org/10.1212/WNL.0b013e3181d6476a

Fenili, D., Brown, M., Rappaport, R. et al. (2007). Properties of scyllo-inositol as a therapeutic treatment of AD-like pathology. J Mol Med (Berl) 85, 603-611. http://dx.doi.org/10.1007/ s00109-007-0156-7

Ferri, C. P., Ames, D., Prince, M. et al. (2004). Behavioral and psychological symptoms of dementia in developing countries. Int Psychogeriatr 16, 441-459.

Fisher, A., Brandeis, R., Bar-Ner, R. H. et al. (2002a). AF150(S) and AF267B: M1 muscarinic agonists as innovative therapies for Alzheimer's disease. J Mol Neurosci 19, 145-153. http:// dx.doi.org/10.1007/s12031-002-0025-3

Fisher, A., Brandeis, R., Haring, R. et al. (2002b). Impact of muscarinic agonists for successful therapy of Alzheimer's disease. J Neural Transm 62, Suppl, 189-202.

Fisher, A., Pittel, Z., Haring, R. et al. (2003). M1 muscarinic agonists can modulate some of the hallmarks in Alzheimer's disease: Implications in future therapy. J Mol Neurosci 20, 349356. http://dx.doi.org/10.1385/JMN:20:3:349

Fitzpatrick, A. L., Kuller, L. H., Lopez, O. L. et al. (2005). Survival following dementia onset: Alzheimer's disease and vascular dementia. J Neurol Sci 229-230, 43-49. http://dx.doi. org/10.1016/j.jns.2004.11.022

Freund-Levi, Y., Hjorth, E., Lindberg, C. et al. (2009). Effects of omega-3 fatty acids on inflammatory markers in cerebrospinal fluid and plasma in Alzheimer's disease: The OmegAD study. Dement Geriatr Cogn Disord 27, 481-490. http://dx.doi. org/10.1159/000218081

Frolich, L., Ashwood, T., Nilsson, J. et al. (2011). Effects of AZD3480 on cognition in patients with mild-to-moderate Alzheimer's disease: A phase IIb dose-finding study. $J$ Alzheimers Dis 24, 363-374. http://dx.doi.org/10.3233/JAD-2011101554

Fu, H., Li, W., Lao, Y. et al. (2006). Bis(7)-tacrine attenuates beta amyloid-induced neuronal apoptosis by regulating L-type calcium channels. J Neurochem 98, 1400-1410. http://dx.doi. org/10.1111/j.1471-4159.2006.03960.x

Fu, H., Li, W., Luo, J. et al. (2008). Promising anti-Alzheimer's 
dimer bis(7)-tacrine reduces beta-amyloid generation by directly inhibiting BACE-1 activity. Biochem Biophys Res Commun 366, 631-636. http://dx.doi.org/10.1016/j.bbrc.2007.11.068

Games, D., Adams, D., Alessandrini, R. et al. (1995). Alzheimertype neuropathology in transgenic mice overexpressing V717F beta-amyloid precursor protein. Nature 373, 523-527. http:// dx.doi.org/10.1038/373523a0

Ganguli, M., Dodge, H. H., Shen, C. et al. (2005). Alzheimer disease and mortality: A 15-year epidemiological study. Arch Neurol 62, 779-784. http://dx.doi.org/10.1001/archneur.62.5.779

Garnier, J. P. (2008). Rebuilding the R\&D engine in big pharma. Harv Bus Rev 86, 68-70, 72-66, 128.

Gatto, G. J., Bohme, G. A., Caldwell, W. S. et al. (2004). TC1734: An orally active neuronal nicotinic acetylcholine receptor modulator with antidepressant, neuroprotective and long-lasting cognitive effects. CNS Drug Rev 10, 147-166.

Gatz, M., Reynolds, C. A., Fratiglioni, L. et al. (2006). Role of genes and environments for explaining Alzheimer disease. Arch Gen Psychiatry 63, 168-174. http://dx.doi.org/10.1001/ archpsyc.63.2.168

Gearing, M., Rebeck, G. W., Hyman, B. T. et al. (1994). Neuropathology and apolipoprotein $\mathrm{E}$ profile of aged chimpanzees: Implications for Alzheimer disease. Proc Natl Acad Sci U S A 91, 9382-9386.

Gearing, M., Tigges, J., Mori, H. et al. (1996). A beta40 is a major form of beta-amyloid in nonhuman primates. Neurobiol Aging 17, 903-908.

Gearing, M., Tigges, J., Mori, H. et al. (1997). beta-Amyloid (A beta) deposition in the brains of aged orangutans. Neurobiol Aging 18, 139-146.

Geghman, K. and Li, C. (2011). Practical considerations of genetic rodent models for neurodegenerative diseases. Methods Mol Biol 793, 185-193. http://dx.doi.org/10.1007/978-1-61779328-8_12

Geling, A., Steiner, H., Willem, M. et al. (2002). A gamma-secretase inhibitor blocks Notch signaling in vivo and causes a severe neurogenic phenotype in zebrafish. EMBO Rep 3, 688-694. http://dx.doi.org/10.1093/embo-reports/kvf124

Gervais, F., Chalifour, R., Garceau, D. et al. (2001). Glycosaminoglycan mimetics: A therapeutic approach to cerebral amyloid angiopathy. Amyloid 8, Suppl 1, 28-35.

Gervais, F., Paquette, J., Morissette, C. et al. (2007). Targeting soluble Abeta peptide with Tramiprosate for the treatment of brain amyloidosis. Neurobiol Aging 28, 537-547. http://dx.doi. org/10.1016/j.neurobiolaging.2006.02.015

Ghribi, O., Golovko, M. Y., Larsen, B. et al. (2006). Deposition of iron and beta-amyloid plaques is associated with cortical cellular damage in rabbits fed with long-term cholesterol-enriched diets. J Neurochem 99, 438-449. http://dx.doi.org/10.1111/ j.1471-4159.2006.04079.x

Glenner, G. G. and Wong, C. W. (1984). Alzheimer's disease: Initial report of the purification and characterization of a novel cerebrovascular amyloid protein. Biochem Biophys Res Commun 120, 885-890.

Goate, A., Chartier-Harlin, M. C., Mullan, M. et al. (1991). Segregation of a missense mutation in the amyloid precursor protein gene with familial Alzheimer's disease. Nature 349, 704-706. http://dx.doi.org/10.1038/349704a0

Gold, M., Alderton, C., Zvartau-Hind, M. et al. (2010). Rosiglitazone monotherapy in mild-to-moderate Alzheimer's disease: Results from a randomized, double-blind, placebo-controlled phase III study. Dement Geriatr Cogn Disord 30, 131-146. http://dx.doi.org/10.1159/000318845

Gonzalez-Lima, F., Berndt, J. D., Valla, J. E. et al. (2001). Reduced corpus callosum, fornix and hippocampus in PDAPP transgenic mouse model of Alzheimer's disease. Neuroreport 12, 2375-2379.

Gotz, J., Probst, A., Spillantini, M. G. et al. (1995). Somatodendritic localization and hyperphosphorylation of tau protein in transgenic mice expressing the longest human brain tau isoform. ЕMBO J 14, 1304-1313.

Gotz, J., Chen, F., van Dorpe, J. et al. (2001). Formation of neurofibrillary tangles in P3011 tau transgenic mice induced by Abeta 42 fibrils. Science 293, 1491-1495. http://dx.doi.org/10.1126/ science. 1062097

Green, R. C., Schneider, L. S., Amato, D. A. et al. (2009). Effect of tarenflurbil on cognitive decline and activities of daily living in patients with mild Alzheimer disease: A randomized controlled trial. JAMA 302, 2557-2564. http://dx.doi.org/10.1001/ jama.2009.1866

Grunblatt, E., Hoyer, S. and Riederer, P. (2004). Gene expression profile in streptozotocin rat model for sporadic Alzheimer's disease. J Neural Transm 111, 367-386. http://dx.doi.org/10.1007/ s00702-003-0030-X

Gutteridge, J. M. (1994). Hydroxyl radicals, iron, oxidative stress, and neurodegeneration. Ann N Y Acad Sci 738, 201-213.

Haag, M. D., Hofman, A., Koudstaal, P. J. et al. (2009). Statins are associated with a reduced risk of Alzheimer disease regardless of lipophilicity. The Rotterdam Study. J Neurol Neurosurg Psychiatry 80, 13-17. http://dx.doi.org/10.1136/jnnp.2008.150433

Hardy, J. A. and Higgins, G. A. (1992). Alzheimer's disease: The amyloid cascade hypothesis. Science 256, 184-185.

Hare, B. and Tomasello, M. (2005). Human-like social skills in dogs? Trends Cogn Sci 9, 439-444. http://dx.doi.org/10.1016/j. tics.2005.07.003

Haroutunian, V., Greig, N., Pei, X. F. et al. (1997). Pharmacological modulation of Alzheimer's beta-amyloid precursor protein levels in the CSF of rats with forebrain cholinergic system lesions. Brain Res Mol Brain Res 46, 161-168.

Harrison, S. M., Harper, A. J., Hawkins, J. et al. (2003). BACE1 (beta-secretase) transgenic and knockout mice: Identification of neurochemical deficits and behavioral changes. $\mathrm{Mol} \mathrm{Cell} \mathrm{Neu}$ rosci $24,646-655$.

Head, E., Mehta, R., Hartley, J. et al. (1995). Spatial learning and memory as a function of age in the dog. Behav Neurosci 109, 851-858.

Head, E., Callahan, H., Muggenburg, B. A. et al. (1998). Visualdiscrimination learning ability and beta-amyloid accumulation in the dog. Neurobiol Aging 19, 415-425.

Head, E., McCleary, R., Hahn, F. F. et al. (2000). Region-specific age at onset of beta-amyloid in dogs. Neurobiol Aging 21, 8996.

Hebert, L. E., Weuve, J., Scherr, P. A. et al. (2013). Alzheimer disease in the United States (2010-2050) estimated using the 2010 
census. Neurology 80, 1778-1783. http://dx.doi.org/10.1212/ WNL.0b013e31828726f5

Heinrich, J. N., Butera, J. A., Carrick, T. et al. (2009). Pharmacological comparison of muscarinic ligands: Historical versus more recent muscarinic M1-preferring receptor agonists. Eur J Pharmacol 605, 53-56. http://dx.doi.org/10.1016/j. ejphar.2008.12.044

Heneka, M. T., Sastre, M., Dumitrescu-Ozimek, L. et al. (2005). Acute treatment with the PPARgamma agonist pioglitazone and ibuprofen reduces glial inflammation and Abeta1-42 levels in APPV717I transgenic mice. Brain 128, 1442-1453. http:// dx.doi.org/10.1093/brain/awh452

Henley, D. B., May, P. C., Dean, R. A. et al. (2009). Development of semagacestat (LY450139), a functional gammasecretase inhibitor, for the treatment of Alzheimer's disease. Expert Opin Pharmacother 10, 1657-1664. http://dx.doi.org/ $10.1517 / 14656560903044982$

Herzig, M. C., Winkler, D. T., Burgermeister, P. et al. (2004). Abeta is targeted to the vasculature in a mouse model of hereditary cerebral hemorrhage with amyloidosis. Nat Neurosci 7 , 954-960. http://dx.doi.org/10.1038/nn1302

Hilt, D.C., Gawryl, M., Koenig, G. et al. (2012). EVP-6124, A selective Alpha-7 partial agonist, has positive effects on cognition and clinical function in mild to moderate Alzheimer's disease patients: Results of a six-month, double-blind, placebo controlled, dose ranging study. http://www.envivopharma.com/pdf/ EVP-6124AAICPressConf.pdf

Hock, C., Maddalena, A., Raschig, A. et al. (2003). Treatment with the selective muscarinic $\mathrm{m} 1$ agonist talsaclidine decreases cerebrospinal fluid levels of A beta 42 in patients with Alzheimer's disease. Amyloid 10, 1-6.

Holcomb, L., Gordon, M. N., McGowan, E. et al. (1998). Accelerated Alzheimer-type phenotype in transgenic mice carrying both mutant amyloid precursor protein and presenilin 1 transgenes. Nat Med 4, 97-100.

Honjo, K., Black, S. E. and Verhoeff, N. P. (2012). Alzheimer's disease, cerebrovascular disease, and the beta-amyloid cascade. Can J Neurol Sci 39, 712-728.

Hou, Y., White, R. G., Bobik, M. et al. (1997). Distribution of beta-amyloid in the canine brain. Neuroreport 8, 1009-1012.

Hsia, A. Y., Masliah, E., McConlogue, L. et al. (1999). Plaqueindependent disruption of neural circuits in Alzheimer's disease mouse models. Proc Natl Acad Sci U S A 96, 3228-3233.

Hsiao, K., Chapman, P., Nilsen, S. et al. (1996). Correlative memory deficits, Abeta elevation, and amyloid plaques in transgenic mice. Science 274, 99-102.

Humpel, C. (2011). Identifying and validating biomarkers for Alzheimer's disease. Trends Biotechnol 29, 26-32. http://dx.doi. org/10.1016/j.tibtech.2010.09.007

Ieda, M. (2013). Direct reprogramming into desired cell types by defined factors. Keio J Med 62, 74-82.

Imbimbo, B. P. and Giardina, G. A. (2011). gamma-secretase inhibitors and modulators for the treatment of Alzheimer's disease: Disappointments and hopes. Curr Top Med Chem 11, 1555-1570.

Imbimbo, B. P., Ottonello, S., Frisardi, V. et al. (2012). Solanezumab for the treatment of mild-to-moderate Alzheimer's disease.
Expert Rev Clin Immunol 8, 135-149. http://dx.doi.org/10.1586/ eci.11.93

Inestrosa, N. C., Alvarez, A., Perez, C. A. et al. (1996). Acetylcholinesterase accelerates assembly of amyloid-beta-peptides into Alzheimer's fibrils: Possible role of the peripheral site of the enzyme. Neuron 16,881-891.

Irizarry, M. C., Soriano, F., McNamara, M. et al. (1997). Abeta deposition is associated with neuropil changes, but not with overt neuronal loss in the human amyloid precursor protein V717F (PDAPP) transgenic mouse. J Neurosci 17, 7053-7059.

Irvine, G. B., El-Agnaf, O. M., Shankar, G. M. et al. (2008). Protein aggregation in the brain: The molecular basis for Alzheimer's and Parkinson's diseases. Mol Med 14, 451-464. http:// dx.doi.org/10.2119/2007-00100.Irvine

Isaac, M. G., Quinn, R. and Tabet, N. (2008). Vitamin E for Alzheimer's disease and mild cognitive impairment. Cochrane Database Syst Rev, CD002854. http://dx.doi.org/10.1002/14651858. CD002854.pub2

Ishihara, T., Hong, M., Zhang, B. et al. (1999). Age-dependent emergence and progression of a tauopathy in transgenic mice overexpressing the shortest human tau isoform. Neuron 24, 751-762.

Iwatsubo, T., Odaka, A., Suzuki, N. et al. (1994). Visualization of A beta 42(43) and A beta 40 in senile plaques with end-specific A beta monoclonals: Evidence that an initially deposited species is A beta 42(43). Neuron 13,45-53.

Johnstone, E. M., Chaney, M. O., Norris, F. H. et al. (1991). Conservation of the sequence of the Alzheimer's disease amyloid peptide in dog, polar bear and five other mammals by cross-species polymerase chain reaction analysis. Brain Res Mol Brain Res 10, 299-305.

Kalback, W., Watson, M. D., Kokjohn, T. A. et al. (2002). APP transgenic mice $\operatorname{Tg} 2576$ accumulate A beta peptides that are distinct from the chemically modified and insoluble peptides deposited in Alzheimer's disease senile plaques. Biochemistry 41, 922-928.

Kanemaru, K., Iwatsubo, T. and Ihara, Y. (1996). Comparable amyloid beta-protein (A beta) 42(43) and A beta 40 deposition in the aged monkey brain. Neurosci Lett 214, 196-198.

Kavanagh, S., Van Baelen, B. and Schauble, B. (2011). Long-term effects of galantamine on cognitive function in Alzheimer's disease: A large-scale international retrospective study. J Alzheimers Dis 27, 521-530. http://dx.doi.org/10.3233/JAD-2011110417

Kiatipattanasakul, W., Nakayama, H., Yongsiri, S. et al. (2000). Abnormal neuronal and glial argyrophilic fibrillary structures in the brain of an aged albino cynomolgus monkey (Macaca fascicularis). Acta Neuropathol 100, 580-586.

Kim, E. S., Carrigan, T. P. and Menon, V. (2011). International participation in cardiovascular randomized controlled trials sponsored by the National Heart, Lung, and Blood Institute. J Am Coll Cardiol 58, 671-676. http://dx.doi.org/10.1016/j. jacc.2011.01.066

Kingwell, K. (2012). Alzheimer disease: Amyloid-beta immunotherapy CAD106 passes first safety test in patients with Alzheimer disease. Nat Rev Neurol 8, 414. http://dx.doi.org/10.1038/ nrneurol.2012.128 
Kirkby, D. L., Jones, D. N., Barnes, J. C. et al. (1996). Effects of anticholinesterase drugs tacrine and E2020, the 5-HT(3) antagonist ondansetron, and the $\mathrm{H}(3)$ antagonist thioperamide, in models of cognition and cholinergic function. Behav Pharmacol 7, 513-525.

Klein, J. (2007). Phenserine. Expert Opin Investig Drugs 16, 1087-1097. http://dx.doi.org/10.1517/13543784.16.7.1087

Kosik, K. S., Joachim, C. L. and Selkoe, D. J. (1986). Microtubule-associated protein tau (tau) is a major antigenic component of paired helical filaments in Alzheimer disease. Proc Natl Acad Sci U S A 83, 4044-4048.

Kukar, T., Prescott, S., Eriksen, J. L. et al. (2007). Chronic administration of R-flurbiprofen attenuates learning impairments in transgenic amyloid precursor protein mice. BMC Neurosci 8 , 54. http://dx.doi.org/10.1186/1471-2202-8-54

Kuo, Y. M., Kokjohn, T. A., Beach, T. G. et al. (2001). Comparative analysis of amyloid-beta chemical structure and amyloid plaque morphology of transgenic mouse and Alzheimer's disease brains. J Biol Chem 276, 12991-12998. http://dx.doi. org/10.1074/jbc.M007859200

Landsberg, G. (2005). Therapeutic agents for the treatment of cognitive dysfunction syndrome in senior dogs. Prog Neuropsychopharmacol Biol Psychiatry 29, 471-479. http://dx.doi. org/10.1016/j.pnpbp.2004.12.012

Langui, D., Girardot, N., El Hachimi, K. H. et al. (2004). Subcellular topography of neuronal Abeta peptide in APPxPS1 transgenic mice. Am J Pathol 165, 1465-1477.

Lanz, T. A., Himes, C. S., Pallante, G. et al. (2003). The gammasecretase inhibitor $\mathrm{N}$-[N-(3,5-difluorophenacetyl)-L-alanyl]S-phenylglycine t-butyl ester reduces A beta levels in vivo in plasma and cerebrospinal fluid in young (plaque-free) and aged (plaque-bearing) Tg2576 mice. J Pharmacol Exp Ther 305, 864-871. http://dx.doi.org/10.1124/jpet.102.048280

La Porte, S. L., Bollini, S. S., Lanz, T. A. et al. (2012). Structural basis of C-terminal beta-amyloid peptide binding by the antibody ponezumab for the treatment of Alzheimer's disease. $\mathrm{J} \mathrm{Mol}$ Biol 421, 525-536. http://dx.doi.org/10.1016/j.jmb.2011.11.047

Larson, E. B., Wang, L., Bowen, J. D. et al. (2006). Exercise is associated with reduced risk for incident dementia among persons 65 years of age and older. Ann Intern Med 144, 73-81.

Lazarov, O., Morfini, G. A., Pigino, G. et al. (2007). Impairments in fast axonal transport and motor neuron deficits in transgenic mice expressing familial Alzheimer's disease-linked mutant presenilin 1. J Neurosci 27, 7011-7020. http://dx.doi. org/10.1523/JNEUROSCI.4272-06.2007

Lemere, C. A., Oh, J., Stanish, H. A. et al. (2008). Cerebral amyloid-beta protein accumulation with aging in cotton-top tamarins: A model of early Alzheimer's disease? Rejuvenation Res 11, 321-332. http://dx.doi.org/10.1089/rej.2008.0677

Lermontova, N. N., Lukoyanov, N. V., Serkova, T. P. et al. (2000). Dimebon improves learning in animals with experimental Alzheimer's disease. Bull Exp Biol Med 129, 544-546.

Lesne, S., Koh, M. T., Kotilinek, L. et al. (2006). A specific amyloid-beta protein assembly in the brain impairs memory. Nature 440, 352-357. http://dx.doi.org/10.1038/nature04533

Leusch, A., Troger, W., Greischel, A. et al. (2000). Pharmacokinetics of the M1-agonist talsaclidine in mouse, rat, rabbit and monkey, and extrapolation to man. Xenobiotica 30, 797-813. http://dx.doi.org/10.1080/00498250050119853

Levy-Lahad, E., Wasco, W., Poorkaj, P. et al. (1995). Candidate gene for the chromosome 1 familial Alzheimer's disease locus. Science 269, 973-977.

Lewczuk, P., Kornhuber, J., Vanderstichele, H. et al. (2008). Multiplexed quantification of dementia biomarkers in the CSF of patients with early dementias and MCI: A multicenter study. Neurobiol Aging 29,812-818. http://dx.doi.org/10.1016/j. neurobiolaging.2006.12.010

Lewis, J., McGowan, E., Rockwood, J. et al. (2000). Neurofibrillary tangles, amyotrophy and progressive motor disturbance in mice expressing mutant $(\mathrm{P} 301 \mathrm{~L})$ tau protein. Nat Genet 25 , 402-405. http://dx.doi.org/10.1038/78078

Lilja, A. M., Luo, Y., Yu, Q. S. et al. (2013a). Neurotrophic and neuroprotective actions of (-)- and (+)-phenserine, candidate drugs for Alzheimer's disease. PLoS One 8, e54887. http:// dx.doi.org/10.1371/journal.pone.0054887

Lilja, A. M., Rojdner, J., Mustafiz, T. et al. (2013b). Age-dependent neuroplasticity mechanisms in Alzheimer Tg2576 mice following modulation of brain amyloid-beta levels. PLoS One 8, e58752. http://dx.doi.org/10.1371/journal.pone.0058752

Lippiello, P., Letchworth, S. R., Gatto, G. J. et al. (2006). Ispronicline: A novel alpha4beta2 nicotinic acetylcholine receptorselective agonist with cognition-enhancing and neuroprotective properties. J Mol Neurosci 30, 19-20. http://dx.doi.org/10.1385/ JMN:30:1:19

Liu, J., Ho, W., Lee, N. T. et al. (2000). Bis(7)-tacrine, a novel acetylcholinesterase inhibitor, reverses AF64A-induced deficits in navigational memory in rats. Neurosci Lett 282, 165-168.

Lopez-Arrieta, J. M. and Schneider, L. (2006). Metrifonate for Alzheimer's disease. Cochrane Database Syst Rev, CD003155. http://dx.doi.org/10.1002/14651858.CD003155.pub3

Luchsinger, J. A., Tang, M. X., Shea, S. et al. (2002). Caloric intake and the risk of Alzheimer disease. Arch Neurol 59, 12581263.

Luchsinger, J. A., Tang, M. X., Shea, S. et al. (2003). Antioxidant vitamin intake and risk of Alzheimer disease. Arch Neurol 60 , 203-208.

Mangialasche, F., Solomon, A., Winblad, B. et al. (2010). Alzheimer's disease: Clinical trials and drug development. Lancet Neurol 9, 702-716. http://dx.doi.org/10.1016/S14744422(10)70119-8

Marder, K. (2004). Memantine approved to treat moderate to severe Alzheimer's disease. Curr Neurol Neurosci Rep 4, 349350 .

Martin, L. J., Pardo, C. A., Cork, L. C. et al. (1994). Synaptic pathology and glial responses to neuronal injury precede the formation of senile plaques and amyloid deposits in the aging cerebral cortex. Am J Pathol 145, 1358-1381.

Martinez-Coria, H., Green, K. N., Billings, L. M. et al. (2010). Memantine improves cognition and reduces Alzheimer's-like neuropathology in transgenic mice. Am J Pathol 176, 870-880. http://dx.doi.org/10.2353/ajpath.2010.090452

Martone, R. L., Zhou, H., Atchison, K. et al. (2009). Begacestat (GSI-953): A novel, selective thiophene sulfonamide inhibitor of amyloid precursor protein gamma-secretase for the treatment 
of Alzheimer's disease. J Pharmacol Exp Ther 331, 598-608. http://dx.doi.org/10.1124/jpet.109.152975

Masliah, E., Sisk,A., Mallory, M. et al. (2001). Neurofibrillary pathology in transgenic mice overexpressing V717F beta-amyloid precursor protein. J Neuropathol Exp Neurol 60, 357-368.

Masters, C. L., Simms, G., Weinman, N. A. et al. (1985). Amyloid plaque core protein in Alzheimer disease and Down syndrome. Proc Natl Acad Sci U S A 82, 4245-4249.

Matsuoka, Y., Picciano, M., Malester, B. et al. (2001). Inflammatory responses to amyloidosis in a transgenic mouse model of Alzheimer's disease. Am J Pathol 158, 1345-1354. http:// dx.doi.org/10.1016/S0002-9440(10)64085-0

Mattson, M. P., Gary, D. S., Chan, S. L. et al. (2001). Perturbed endoplasmic reticulum function, synaptic apoptosis and the pathogenesis of Alzheimer's disease. Biochem Soc Symp 67, 151-162.

May, P., Boggs, L., Brier, R. et al. (2012). Preclinical characterization of LY2886721: A BACE1 inhibitor in clinical development for early Alzheimer's disease. Alzheimer's and Dementia 8, P95. http://www.alzheimersanddementia.com/article/S1552$5260 \% 2812 \% 2900367-6 /$ fulltext

Mayer, M. L. and Westbrook, G. L. (1987). The physiology of excitatory amino acids in the vertebrate central nervous system. Prog Neurobiol 28, 197-276.

Mayer, S. C., Kreft, A. F., Harrison, B. et al. (2008). Discovery of begacestat, a Notch-1-sparing gamma-secretase inhibitor for the treatment of Alzheimer's disease. J Med Chem 51, 73487351. http://dx.doi.org/10.1021/jm801252w

Mayo Clinic Staff (2013). Risk factors. http://www.mayoclinic. com/health/alzheimers-disease/DS00161/DSECTION=riskfactors

McGowan, E., Sanders, S., Iwatsubo, T. et al. (1999). Amyloid phenotype characterization of transgenic mice overexpressing both mutant amyloid precursor protein and mutant presenilin 1 transgenes. Neurobiol Dis 6, 231-244.http://dx.doi.org/10.1006/ nbdi.1999.0243

McLaurin, J., Kierstead, M. E., Brown, M. E. et al. (2006). Cyclohexanehexol inhibitors of Abeta aggregation prevent and reverse Alzheimer phenotype in a mouse model. Nat Med 12, 801-808. http://dx.doi.org/10.1038/nm1423

Mehlhorn, G., Hollborn, M. and Schliebs, R. (2000). Induction of cytokines in glial cells surrounding cortical beta-amyloid plaques in transgenic Tg2576 mice with Alzheimer pathology. Int J Dev Neurosci 18, 423-431.

Micchelli, C. A., Esler, W. P., Kimberly, W. T. et al. (2003). Gamma-secretase/presenilin inhibitors for Alzheimer's disease phenocopy Notch mutations in Drosophila. FASEB J 17, 79-81. http://dx.doi.org/10.1096/fj.02-0394fje

Middleton, L. E., Mitnitski, A., Fallah, N. et al. (2008). Changes in cognition and mortality in relation to exercise in late life: A population based study. PLoS One 3, e3124. http://dx.doi. org/10.1371/journal.pone.0003124

Miguel-Hidalgo, J. J., Alvarez, X. A., Cacabelos, R. et al. (2002). Neuroprotection by memantine against neurodegeneration induced by beta-amyloid(1-40). Brain Res 958, 210-221.

Miller, B. W., Willett, K. C. and Desilets, A. R. (2011). Rosiglitazone and pioglitazone for the treatment of Alzheimer's disease.
Ann Pharmacother 45, 1416-1424. http://dx.doi.org/10.1345/ aph.1Q238

Minkeviciene, R., Banerjee, P. and Tanila, H. (2004). Memantine improves spatial learning in a transgenic mouse model of Alzheimer's disease. J Pharmacol Exp Ther 311, 677-682. http://dx.doi.org/10.1124/jpet.104.071027

Mitani, Y., Yarimizu, J., Saita, K. et al. (2012). Differential effects between gamma-secretase inhibitors and modulators on cognitive function in amyloid precursor protein-transgenic and nontransgenic mice. J Neurosci 32, 2037-2050. http://dx.doi. org/10.1523/JNEUROSCI.4264-11.2012

Moechars, D., Dewachter, I., Lorent, K. et al. (1999). Early phenotypic changes in transgenic mice that overexpress different mutants of amyloid precursor protein in brain. J Biol Chem 274, 6483-6492.

Morgan, D., Diamond, D. M., Gottschall, P. E. et al. (2000). A beta peptide vaccination prevents memory loss in an animal model of Alzheimer's disease. Nature 408, 982-985. http://dx.doi. org/10.1038/35050116

Mori, F., Cuadra, G. and Giacobini, E. (1995). Metrifonate effects on acetylcholine and biogenic amines in rat cortex. Neurochem Res 20, 1081-1088.

Morris, M. C., Evans, D.A., Bienias, J. L. et al. (2002). Dietary intake of antioxidant nutrients and the risk of incident Alzheimer disease in a biracial community study. JAMA 287, 3230-3237.

Morris, M. C., Evans, D. A., Bienias, J. L. et al. (2003). Consumption of fish and n-3 fatty acids and risk of incident Alzheimer disease. Arch Neurol 60, 940-946. http://dx.doi.org/10.1001/ archneur.60.7.940

Morrissette, D. A., Parachikova, A., Green, K. N. et al. (2009). Relevance of transgenic mouse models to human Alzheimer disease.J Biol Chem 284, 6033-6037. http://dx.doi.org/10.1074/ jbc.R800030200

Mucke, L., Masliah, E., Yu, G. Q. et al. (2000). High-level neuronal expression of abeta 1-42 in wild-type human amyloid protein precursor transgenic mice: Synaptotoxicity without plaque formation. J Neurosci 20,4050-4058.

Mullan, M., Crawford, F., Axelman, K. et al. (1992). A pathogenic mutation for probable Alzheimer's disease in the APP gene at the N-terminus of beta-amyloid. Nat Genet 1, 345-347. http:// dx.doi.org/10.1038/ng0892-345

Nakamura, S., Tamaoka, A., Sawamura, N. et al. (1995). Carboxyl end-specific monoclonal antibodies to amyloid beta protein (A beta) subtypes (A beta 40 and A beta 42(43)) differentiate A beta in senile plaques and amyloid angiopathy in brains of aged cynomolgus monkeys. Neurosci Lett 201, 151-154.

Neale, T. (2010). Novel Alzheimer's Drug Flops. http://www. medpagetoday.com/Neurology/AlzheimersDisease/18794

NIA (1997). Consensus recommendations for the postmortem diagnosis of Alzheimer's disease. The National Institute on Aging, and Reagan Institute Working Group on Diagnostic Criteria for the Neuropathological Assessment of Alzheimer's Disease. Neurobiol Aging 18, S1-2.

NIH (2010). Tolerability and safety of subcutaneous administration of AFFITOPE AD02 in mild to moderate Alzheimer's disease. http://clinicaltrials.gov/ct2/show/NCT00633841

NIH (2011). Safety and efficacy study of ABT-089 in adults with 
mild to moderate Alzheimer's disease. http://www.clinicaltrials. gov/ct2/show/NCT00555204?term=NCT00555204\&rank=1

NIH (2012). Safety and efficacy study of ABT-089 in adults with mild to moderate Alzheimer's disease. http://www.clinicaltrials. gov/ct2/show/NCT00555204?term $=$ NCT00555204\&rank=1

NIH (2013a). Efficacy and safety study of ELND005 as a treatment for agitation and aggression in Alzheimer's disease. http:// www.clinicaltrials.gov/ct2/show/NCT01735630?term=NCT01 735630\&rank $=1$

NIH (2013b). Sunphenon EGCg (Epigallocatechin-Gallate) in the early stage of Alzheimer's disease (SUN-AK). http://clinicaltrials. gov/ct2/show/NCT00951834

NIH (2013c). A study to evaluate the efficacy and safety of MABT5102A in patients with mild to moderate Alzheimer's Dsease (ABBY). http://clinicaltrials.gov/ct2/show/NCT01343 966? term $=$ NCT01343966\&rank $=1$

Niva, C., Parkinson, J., Olsson, F. et al. (2013). Has inhibition of Abeta production adequately been tested as therapeutic approach in mild AD? A model-based meta-analysis of gammasecretase inhibitor data. Eur J Clin Pharmacol 69, 1247-1260. http://dx.doi.org/10.1007/s00228-012-1459-3

Notkola, I. L., Sulkava, R., Pekkanen, J. et al. (1998). Serum total cholesterol, apolipoprotein E epsilon 4 allele, and Alzheimer's disease. Neuroepidemiology 17, 14-20.

Oakley, H., Cole, S. L., Logan, S. et al. (2006). Intraneuronal beta-amyloid aggregates, neurodegeneration, and neuron loss in transgenic mice with five familial Alzheimer's disease mutations: Potential factors in amyloid plaque formation. $\mathrm{J} \mathrm{Neu}$ rosci 26, 10129-10140. http://dx.doi.org/10.1523/JNEURO SCI.1202-06.2006

Obermeyer, T. S., Yonick, D., Lauing, K. et al. (2012). Mesenchymal stem cells facilitate fracture repair in an alcohol-induced impaired healing model. J Orthop Trauma 26, 712-718. http:// dx.doi.org/10.1097/BOT.0b013e3182724298

Oddo, S., Caccamo, A., Shepherd, J. D. et al. (2003). Triple-transgenic model of Alzheimer's disease with plaques and tangles: Intracellular Abeta and synaptic dysfunction. Neuron 39, 409421.

Opii, W. O., Joshi, G., Head, E. et al. (2008). Proteomic identification of brain proteins in the canine model of human aging following a long-term treatment with antioxidants and a program of behavioral enrichment: Relevance to Alzheimer's disease. Neurobiol Aging 29, 51-70. http://dx.doi.org/10.1016/j.neuro biolaging.2006.09.012

Orgogozo, J. M., Gilman, S., Dartigues, J. F. et al. (2003). Subacute meningoencephalitis in a subset of patients with AD after Abeta42 immunization. Neurology 61, 46-54.

Oyama, F., Sawamura, N., Kobayashi, K. et al. (1998). Mutant presenilin 2 transgenic mouse: Effect on an age-dependent increase of amyloid beta-protein 42 in the brain. J Neurochem 71, 313-322.

Panza, F., Solfrizzi, V., Imbimbo, B. P. et al. (2014). Amyloidbased immunotherapy for Alzheimer's disease in the time of prevention trials: The way forward. Expert Rev Clin Immunol 10, 405-419. http://dx.doi.org/10.1586/1744666X.2014. 883921

Papaioannou, N., Tooten, P. C., van Ederen, A. M. et al. (2001).
Immunohistochemical investigation of the brain of aged dogs I. Detection of neurofibrillary tangles and of 4-hydroxynonenal protein, an oxidative damage product, in senile plaques. Amyloid 8, 11-21.

Patel, N., Spangler, E. L., Greig, N. H. et al. (1998). Phenserine, a novel acetylcholinesterase inhibitor, attenuates impaired learning of rats in a 14-unit T-maze induced by blockade of the $\mathrm{N}$ methyl-D-aspartate receptor. Neuroreport 9, 171-176.

Pedersen, W. A., McMillan, P. J., Kulstad, J. J. et al. (2006). Rosiglitazone attenuates learning and memory deficits in $\mathrm{Tg} 2576$ Alzheimer mice. Exp Neurol 199, 265-273. http://dx.doi. org/10.1016/j.expneurol.2006.01.018

Perez, S. E., Nadeem, M., Sadleir, K. R. et al. (2012). Dimebon alters hippocampal amyloid pathology in $3 \times \mathrm{Tg}-\mathrm{AD}$ mice. Int $J$ Physiol Pathophysiol Pharmacol 4, 115-127.

Perez-Tur, J., Froelich, S., Prihar, G. et al. (1995). A mutation in Alzheimer's disease destroying a splice acceptor site in the presenilin-1 gene. Neuroreport 7, 297-301.

Pfizer (2011). Pfizer Pipeline. http://www.pfizer.com/files/ research/pipeline/2011_0228/pipeline_2011_0228.pdf

Pitkala, K. H., Poysti, M. M., Laakkonen, M. L. et al. (2013). Effects of the Finnish Alzheimer Disease Exercise Trial (FINALEX): A randomized controlled trial. JAMA Intern Med 173, 894-901. http://dx.doi.org/10.1001/ jamainternmed.2013.359

Pizzie, R., Hindman, H., Roe, C. M. et al. (2013). Physical activity and cognitive trajectories in cognitively normal adults: The adult children study. Alzheimer Dis Assoc Disord 28, 50-57. http://dx.doi.org/10.1097/WAD.0b013e31829628d4

Podewils, L. J., Guallar, E., Kuller, L. H. et al. (2005). Physical activity, APOE genotype, and dementia risk: Findings from the cardiovascular health cognition study. Am J Epidemiol 161, 639-651. http://dx.doi.org/10.1093/aje/kwi092

Portelius, E., Zhang, B., Gustavsson, M. K. et al. (2009). Effects of gamma-secretase inhibition on the amyloid beta isoform pattern in a mouse model of Alzheimer's disease. Neurodegener Dis 6, 258-262. http://dx.doi.org/10.1159/000264639

Prickaerts, J., Fahrig, T. and Blokland, A. (1999). Cognitive performance and biochemical markers in septum, hippocampus and striatum of rats after an i.c.v. injection of streptozotocin: A correlation analysis. Behav Brain Res 102, 73-88.

Prickaerts, J., van Goethem, N. P., Chesworth, R. et al. (2012). EVP-6124, a novel and selective alpha7 nicotinic acetylcholine receptor partial agonist, improves memory performance by potentiating the acetylcholine response of alpha7 nicotinic acetylcholine receptors. Neuropharmacology 62, 1099-1110. http:// dx.doi.org/10.1016/j.neuropharm.2011.10.024

Prince, M. and Dementia Research, G. (2004). Care arrangements for people with dementia in developing countries. Int J Geriatr Psychiatry 19, 170-177. http://dx.doi.org/10.1002/gps.1046

Probst, A., Gotz, J., Wiederhold, K. H. et al. (2000). Axonopathy and amyotrophy in mice transgenic for human four-repeat tau protein. Acta Neuropathol 99, 469-481.

Puglielli, L., Tanzi, R. E. and Kovacs, D. M. (2003). Alzheimer's disease: The cholesterol connection. Nat Neurosci 6, 345-351. http://dx.doi.org/10.1038/nn0403-345

Pugliese, M., Mascort, J., Mahy, N. et al. (2006). Diffuse beta- 
amyloid plaques and hyperphosphorylated tau are unrelated processes in aged dogs with behavioral deficits. Acta Neuropathol 112, 175-183. http://dx.doi.org/10.1007/s00401-0060087-3

Radak, Z., Hart, N., Sarga, L. et al. (2010). Exercise plays a preventive role against Alzheimer's disease. J Alzheimers Dis 20, 777-783. http://dx.doi.org/10.3233/JAD-2010-091531

Rapp, P. R. and Amaral, D. G. (1992). Individual differences in the cognitive and neurobiological consequences of normal aging. Trends Neurosci 15, 340-345.

Raskind, M. A., Peskind, E. R., Wessel, T. et al. (2000). Galantamine in AD: A 6-month randomized, placebo-controlled trial with a 6-month extension. The Galantamine USA-1 Study Group. Neurology 54, 2261-2268.

Redwine, J. M., Kosofsky, B., Jacobs, R. E. et al. (2003). Dentate gyrus volume is reduced before onset of plaque formation in PDAPP mice: A magnetic resonance microscopy and stereologic analysis. Proc Natl Acad Sci U S A 100, 1381-1386. http:// dx.doi.org/10.1073/pnas.242746599

Reisberg, B., Doody, R., Stoffler, A. et al. (2003). Memantine in moderate-to-severe Alzheimer's disease. N Engl J Med 348, 13331341. http://dx.doi.org/10.1056/NEJMoa013128

Roberts, R. O., Geda, Y. E., Knopman, D. S. et al. (2013). Cardiac disease associated with increased risk of nonamnestic cognitive impairment: Stronger effect on women. JAMA Neurol 70, 374382. http://dx.doi.org/10.1001/jamaneurol.2013.607

Rockenstein, E., Mante, M., Alford, M. et al. (2005). High betasecretase activity elicits neurodegeneration in transgenic mice despite reductions in amyloid-beta levels: Implications for the treatment of Alzheimer disease. J Biol Chem 280, 32957-32967. http://dx.doi.org/10.1074/jbc.M507016200

Rodrigue, K. M., Rieck, J. R., Kennedy, K. M. et al. (2013). Risk factors for beta-amyloid deposition in healthy aging: Vascular and genetic effects. JAMA Neurol 70, 600-606. http://dx.doi. org/10.1001/jamaneurol.2013.1342

Rogaev, E. I., Sherrington, R., Rogaeva, E. A. et al. (1995). Familial Alzheimer's disease in kindreds with missense mutations in a gene on chromosome 1 related to the Alzheimer's disease type 3 gene. Nature 376, 775-778. http://dx.doi. org/10.1038/376775a0

Rogers, S. L. and Friedhoff, L. T. (1996). The efficacy and safety of donepezil in patients with Alzheimer's disease: Results of a US multicentre, randomized, double-blind, placebo-controlled trial. The Donepezil Study Group. Dementia 7, 293-303.

Roher, A. E., Palmer, K. C., Yurewicz, E. C. et al. (1993). Morphological and biochemical analyses of amyloid plaque core proteins purified from Alzheimer disease brain tissue. J Neurochem 61, 1916-1926.

Rose, C., Peoc'h, K., Chasseigneaux, S. et al. (2012). New highly sensitive rodent and human tests for soluble amyloid precursor protein alpha quantification: Preclinical and clinical applications in Alzheimer's disease. BMC Neurosci 13, 84. http:// dx.doi.org/10.1186/1471-2202-13-84

Rosen, R. F., Farberg, A. S., Gearing, M. et al. (2008). Tauopathy with paired helical filaments in an aged chimpanzee. J Comp Neurol 509, 259-270. http://dx.doi.org/10.1002/cne.21744

Rosenberg, P. B. (2005). Clinical aspects of inflammation in
Alzheimer's disease. Int Rev Psychiatry 17, 503-514. http:// dx.doi.org/10.1080/02646830500382037

Rosler, M., Anand, R., Cicin-Sain, A. et al. (1999). Efficacy and safety of rivastigmine in patients with Alzheimer's disease: international randomised controlled trial. BMJ 318, 633-638.

Ross, C. A. and Poirier, M. A. (2004). Protein aggregation and neurodegenerative disease. Nat Med 10, Suppl, S10-17. http:// dx.doi.org/10.1038/nm1066

Rossor, M. N., Fox, N. C., Freeborough, P. A. et al. (1996). Clinical features of sporadic and familial Alzheimer's disease. Neurodegeneration 5, 393-397.

Rovio, S., Kareholt, I., Helkala, E. L. et al. (2005). Leisuretime physical activity at midlife and the risk of dementia and Alzheimer's disease. Lancet Neurol 4, 705-711. http://dx.doi. org/10.1016/S1474-4422(05)70198-8

Rubio-Perez, J. M. and Morillas-Ruiz, J. M. (2012). A review: Inflammatory process in Alzheimer's disease, role of cytokines. ScientificWorldJournal 2012, 756357. http://dx.doi. org/10.1100/2012/756357

Rueter, L. E., Anderson, D. J., Briggs, C. A. et al. (2004). ABT089: Pharmacological properties of a neuronal nicotinic acetylcholine receptor agonist for the potential treatment of cognitive disorders. CNS Drug Rev 10, 167-182.

Sadigh-Eteghad, S., Talebi, M. and Farhoudi, M. (2012). Association of apolipoprotein E epsilon 4 allele with sporadic late onset Alzheimer's disease. A meta-analysis. Neurosciences (Riyadh) 17, 321-326.

Salem, N., Jr., Wegher, B., Mena, P. et al. (1996). Arachidonic and docosahexaenoic acids are biosynthesized from their 18-carbon precursors in human infants. Proc Natl Acad Sci U S A 93, 4954.

Salkovic-Petrisic, M., Tribl, F., Schmidt, M. et al. (2006). Alzheimer-like changes in protein kinase B and glycogen synthase kinase- 3 in rat frontal cortex and hippocampus after damage to the insulin signalling pathway. $J$ Neurochem 96, 1005-1015. http://dx.doi.org/10.1111/j.1471-4159.2005.03637.x

Salkovic-Petrisic, M., Knezovic, A., Hoyer, S. et al. (2013). What have we learned from the streptozotocin-induced animal model of sporadic Alzheimer's disease, about the therapeutic strategies in Alzheimer's research. J Neural Transm 120, 233-252. http://dx.doi.org/10.1007/s00702-012-0877-9

Salloway, S., Sperling, R., Gilman, S. et al. (2009). A phase 2 multiple ascending dose trial of bapineuzumab in mild to moderate Alzheimer disease. Neurology 73, 2061-2070. http://dx.doi. org/10.1212/WNL.0b013e3181c67808

Salloway, S., Sperling, R., Keren, R. et al. (2011). A phase 2 randomized trial of ELND005, scyllo-inositol, in mild to moderate Alzheimer disease. Neurology 77, 1253-1262. http://dx.doi. org/10.1212/WNL.0b013e3182309fa5

Sampson, E. L., Jenagaratnam, L. and McShane, R. (2012). Metal protein attenuating compounds for the treatment of Alzheimer's dementia. Cochrane Database Syst Rev 5, CD005380. http:// dx.doi.org/10.1002/14651858.CD005380.pub4

Samson, K. (2010). NerveCenter: Phase III Alzheimer trial halted: Search for therapeutic biomarkers continues. Ann Neurol 68, A9-A12. http://dx.doi.org/10.1002/ana.22249

Sarasa, M. and Pesini, P. (2009). Natural non-trasgenic animal 
models for research in Alzheimer's disease. Curr Alzheimer Res 6, 171-178.

Satou, T., Cummings, B. J., Head, E. et al. (1997). The progression of beta-amyloid deposition in the frontal cortex of the aged canine. Brain Res 774, 35-43.

Sawamura, N., Morishima-Kawashima, M., Waki, H. et al. (2000). Mutant presenilin 2 transgenic mice. A large increase in the levels of Abeta 42 is presumably associated with the low density membrane domain that contains decreased levels of glycerophospholipids and sphingomyelin. J Biol Chem 275, 2790127908. http://dx.doi.org/10.1074/jbc.M004308200

Scarmeas, N., Luchsinger, J. A., Schupf, N. et al. (2009). Physical activity, diet, and risk of Alzheimer disease. JAMA 302, 627637. http://dx.doi.org/10.1001/jama.2009.1144

Schaefer, E. J., Bongard, V., Beiser, A. S. et al. (2006). Plasma phosphatidylcholine docosahexaenoic acid content and risk of dementia and Alzheimer disease: The Framingham Heart Study. Arch Neurol 63, 1545-1550. http://dx.doi.org/10.1001/ archneur.63.11.1545

Schaeffer, E. L., Figueiro, M. and Gattaz, W. F. (2011). Insights into Alzheimer disease pathogenesis from studies in transgenic animal models. Clinics (Sao Paulo) 66, Suppl 1, 45-54.

Schellenberg, G. D., Bird, T. D., Wijsman, E. M. et al. (1992). Genetic linkage evidence for a familial Alzheimer's disease locus on chromosome 14. Science 258, 668-671.

Schenk, D., Barbour, R., Dunn, W. et al. (1999). Immunization with amyloid-beta attenuates Alzheimer-disease-like pathology in the PDAPP mouse. Nature 400, 173-177. http://dx.doi. org/10.1038/22124

Schindowski, K., Bretteville, A., Leroy, K. et al. (2006). Alzheimer's disease-like tau neuropathology leads to memory deficits and loss of functional synapses in a novel mutated tau transgenic mouse without any motor deficits. Am J Pathol 169, 599-616. http://dx.doi.org/10.2353/ajpath.2006.060002

Schmitz, C., Rutten, B. P., Pielen, A. et al. (2004). Hippocampal neuron loss exceeds amyloid plaque load in a transgenic mouse model of Alzheimer's disease. Am J Pathol 164, 1495-1502. http://dx.doi.org/10.1016/S0002-9440(10)63235-X

Schneeberger, A., Mandler, M., Otawa, O. et al. (2009). Development of AFFITOPE vaccines for Alzheimer's disease (AD)from concept to clinical testing. J Nutr Health Aging 13, 264267.

Schneider, J., Murray, J., Banerjee, S. et al. (1999). EUROCARE: A cross-national study of co-resident spouse carers for people with Alzheimer's disease: I-Factors associated with carer burden. Int J Geriatr Psychiatry 14, 651-661.

Schroeter, E. H., Ilagan, M. X., Brunkan, A. L. et al. (2003). A presenilin dimer at the core of the gamma-secretase enzyme: Insights from parallel analysis of Notch 1 and APP proteolysis. Proc Natl Acad Sci U S A 100, 13075-13080. http://dx.doi. org/10.1073/pnas.1735338100

Schultz, C., Hubbard, G. B., Rub, U. et al. (2000). Age-related progression of tau pathology in brains of baboons. Neurobiol Aging 21, 905-912.

Schulz, R. and Beach, S. R. (1999). Caregiving as a risk factor for mortality: The Caregiver health effects study. JAMA 282, 2215-2219.
Schulz, R. and Martire, L. M. (2004). Family caregiving of persons with dementia: Prevalence, health effects, and support strategies. Am J Geriatr Psychiatry 12, 240-249.

Schwab, C., Hosokawa, M. and McGeer, P. L. (2004). Transgenic mice overexpressing amyloid beta protein are an incomplete model of Alzheimer disease. Exp Neurol 188, 52-64. http:// dx.doi.org/10.1016/j.expneurol.2004.03.016

Sergeant, N., Bombois, S., Ghestem, A. et al. (2003). Truncated beta-amyloid peptide species in pre-clinical Alzheimer's disease as new targets for the vaccination approach. J Neurochem 85, 1581-1591.

Sherrington, R., Rogaev, E. I., Liang, Y. et al. (1995). Cloning of a gene bearing missense mutations in early-onset familial Alzheimer's disease. Nature 375, 754-760. http://dx.doi. org/10.1038/375754a0

Shoji, M., Golde, T. E., Ghiso, J. et al. (1992). Production of the Alzheimer amyloid beta protein by normal proteolytic processing. Science 258, 126-129.

Shukkur, E. A., Shimohata, A., Akagi, T. et al. (2006). Mitochondrial dysfunction and tau hyperphosphorylation in Ts1Cje, a mouse model for Down syndrome. Hum Mol Genet 15, 27522762. http://dx.doi.org/10.1093/hmg/ddl211

Siddiqi, Z. A. and Peters, A. (1999). The effect of aging on pars compacta of the substantia nigra in rhesus monkey. $\mathrm{J} \mathrm{Neu}$ ropathol Exp Neurol 58, 903-920.

Simonian, N. A. and Coyle, J. T. (1996). Oxidative stress in neurodegenerative diseases. Annu Rev Pharmacol Toxicol 36, 83106. http://dx.doi.org/10.1146/annurev.pa.36.040196.000503

Smid, S. D., Maag, J. L. and Musgrave, I. F. (2012). Dietary polyphenol-derived protection against neurotoxic beta-amyloid protein: From molecular to clinical. Food Funct 3, 1242-1250. http://dx.doi.org/10.1039/c2fo30075c

Smith, J. C., Nielson, K. A., Antuono, P. et al. (2013). Semantic memory functional MRI and cognitive function after exercise intervention in mild cognitive impairment. J Alzheimers Dis 37, 197-215. http://dx.doi.org/10.3233/JAD-130467

Smith, M. A. and Perry, G. (1995). Free radical damage, iron, and Alzheimer's disease. J Neurol Sci 134, Suppl, 92-94.

Sopher, B. L., Fukuchi, K., Kavanagh, T. J. et al. (1996). Neurodegenerative mechanisms in Alzheimer disease. A role for oxidative damage in amyloid beta protein precursor-mediated cell death. Mol Chem Neuropathol 29, 153-168.

Sparks, D. L. and Schreurs, B. G. (2003). Trace amounts of copper in water induce beta-amyloid plaques and learning deficits in a rabbit model of Alzheimer's disease. Proc Natl Acad Sci U S A 100, 11065-11069. http://dx.doi.org/10.1073/pnas.1832769100

Spencer, N. G., Bridges, L. R., Elderfield, K. et al. (2013). Quantitative evaluation of MRI and histological characteristics of the 5xFAD Alzheimer mouse brain. Neuroimage 76, 108-115. http://dx.doi.org/10.1016/j.neuroimage.2013.02.071

Spillantini, M. G., Murrell, J. R., Goedert, M. et al. (1998). Mutation in the tau gene in familial multiple system tauopathy with presenile dementia. Proc Natl Acad Sci U S A 95, 7737-7741.

Spittaels, K., Van den Haute, C., Van Dorpe, J. et al. (1999). Prominent axonopathy in the brain and spinal cord of transgenic mice overexpressing four-repeat human tau protein. Am J Pathol 155, 2153-2165. http://dx.doi.org/10.1016/S0002-9440(10)65533-2 
Steele, J. W. and Gandy, S. (2013). Latrepirdine (Dimebon(R)), a potential Alzheimer therapeutic, regulates autophagy and neuropathology in an Alzheimer mouse model. Autophagy 9, 617618. http://dx.doi.org/10.4161/auto.23487

Strittmatter, W. J., Saunders, A. M., Schmechel, D. et al. (1993). Apolipoprotein E: High-avidity binding to beta-amyloid and increased frequency of type 4 allele in late-onset familial Alzheimer disease. Proc Natl Acad Sci U S A 90, 1977-1981.

Sturchler-Pierrat, C., Abramowski, D., Duke, M. et al. (1997). Two amyloid precursor protein transgenic mouse models with Alzheimer disease-like pathology. Proc Natl Acad Sci U S A 94, 13287-13292.

Su, Y., Ryder, J., Li, B. et al. (2004). Lithium, a common drug for bipolar disorder treatment, regulates amyloid-beta precursor protein processing. Biochemistry 43, 6899-6908. http://dx.doi. org/10.1021/bi035627j

Sudduth, T. L., Greenstein, A. and Wilcock, D. M. (2013). Intracranial injection of Gammagard, a human IVIg, modulates the inflammatory response of the brain and lowers Abeta in APP/ PS1 mice along a different time course than anti-Abeta antibodies. J Neurosci 33, 9684-9692. http://dx.doi.org/10.1523/ JNEUROSCI.1220-13.2013

Sullivan, J. P., Donnelly-Roberts, D., Briggs, C. A. et al. (1997). ABT-089 [2-methyl-3-(2-(S)-pyrrolidinylmethoxy)pyridine]: I. A potent and selective cholinergic channel modulator with neuroprotective properties. J Pharmacol Exp Ther 283, 235-246.

Sweeney, J. E., Hohmann, C. F., Moran, T. H. et al. (1988). A long-acting cholinesterase inhibitor reverses spatial memory deficits in mice. Pharmacol Biochem Behav 31, 141-147.

Sweeney, J. E., Puttfarcken, P. S. and Coyle, J. T. (1989). Galanthamine, an acetylcholinesterase inhibitor: A time course of the effects on performance and neurochemical parameters in mice. Pharmacol Biochem Behav 34, 129-137.

Tai, L. M., Bilousova, T., Jungbauer, L. et al. (2013). Levels of soluble apolipoprotein E/amyloid-beta (Abeta) complex are reduced and oligomeric Abeta increased with APOE4 and Alzheimer disease in a transgenic mouse model and human samples. J Biol Chem 288, 5914-5926. http://dx.doi.org/10.1074/jbc. M112.442103

Tanemura, K., Murayama, M., Akagi, T. et al. (2002). Neurodegeneration with tau accumulation in a transgenic mouse expressing V337M human tau. J Neurosci 22, 133-141.

Tapp, P. D., Siwak, C. T., Estrada, J. et al. (2003). Effects of age on measures of complex working memory span in the beagle dog (Canis familiaris) using two versions of a spatial list learning paradigm. Learn Mem 10, 148-160. http://dx.doi.org/10.1101/ $\operatorname{lm} .56503$

Tayeb, H. O., Murray, E. D., Price, B. H. et al. (2013). Bapineuzumab and solanezumab for Alzheimer's disease: Is the 'amyloid cascade hypothesis' still alive? Expert Opin Biol Ther 13, 10751084. http://dx.doi.org/10.1517/14712598.2013.789856

Terry, R. D., Masliah, E., Salmon, D. P. et al. (1991). Physical basis of cognitive alterations in Alzheimer's disease: Synapse loss is the major correlate of cognitive impairment. Ann Neurol 30, 572-580. http://dx.doi.org/10.1002/ana.410300410

Thambisetty, M. and Lovestone, S. (2010). Blood-based biomarkers of Alzheimer's disease: Challenging but feasible. Biomark
Med 4, 65-79.

Thyagarajan, T., Totey, S., Danton, M. J. et al. (2003). Genetically altered mouse models: The good, the bad, and the ugly. Crit Rev Oral Biol Med 14, 154-174.

Toman, P. D., Pieper, F., Sakai, N. et al. (1999). Production of recombinant human type I procollagen homotrimer in the mammary gland of transgenic mice. Transgenic Res 8, 415-427.

Torp, R., Head, E. and Cotman, C. W. (2000). Ultrastructural analyses of beta-amyloid in the aged dog brain: Neuronal betaamyloid is localized to the plasma membrane. Prog Neuropsychopharmacol Biol Psychiatry 24, 801-810.

Urbanc, B., Cruz, L., Le, R. et al. (2002). Neurotoxic effects of thioflavin S-positive amyloid deposits in transgenic mice and Alzheimer's disease. Proc Natl Acad Sci U S A 99, 1399013995. http://dx.doi.org/10.1073/pnas.222433299

Valla, J., Schneider, L. E., Gonzalez-Lima, F. et al. (2006). Nonprogressive transgene-related callosal and hippocampal changes in PDAPP mice. Neuroreport 17, 829-832. http://dx.doi. org/10.1097/01.wnr.0000220140.91294.15

Van Dam, D., Coen, K. and De Deyn, P. P. (2008). Cognitive evaluation of disease-modifying efficacy of donepezil in the APP23 mouse model for Alzheimer's disease. Psychopharmacology (Berl) 197, 37-43. http://dx.doi.org/10.1007/ s00213-007-1010-x

van Gelder, B. M., Tijhuis, M., Kalmijn, S. et al. (2007). Fish consumption, n-3 fatty acids, and subsequent 5-y cognitive decline in elderly men: The Zutphen Elderly study. Am J Clin Nutr 85, 1142-1147.

Veerhuis, R. (2011). Histological and direct evidence for the role of complement in the neuroinflammation of AD. Curr Alzheimer Res 8, 34-58.

Vellas, B., Black, R., Thal, L. J. et al. (2009). Long-term follow-up of patients immunized with AN1792: Reduced functional decline in antibody responders. Curr Alzheimer Res 6, 144-151.

Vellas, B., Sol, O., Snyder, P. J. et al. (2011). EHT0202 in Alzheimer's disease: A 3-month, randomized, placebo-controlled, double-blind study. Curr Alzheimer Res 8, 203-212.

Verwey, N. A., van der Flier, W. M., Blennow, K. et al. (2009). A worldwide multicentre comparison of assays for cerebrospinal fluid biomarkers in Alzheimer's disease. Ann Clin Biochem 46, 235-240. http://dx.doi.org/10.1258/acb.2009.008232

Voytko, M. L. (1998). Nonhuman primates as models for aging and Alzheimer's disease. Lab Anim Sci 48, 611-617.

Walsh, D. M., Tseng, B. P., Rydel, R. E. et al. (2000). The oligomerization of amyloid beta-protein begins intracellularly in cells derived from human brain. Biochemistry 39, 10831-10839.

Walsh, D. M. and Selkoe, D. J. (2007). A beta oligomers - a decade of discovery. J Neurochem 101, 1172-1184. http://dx.doi. org/10.1111/j.1471-4159.2006.04426.x

Wegiel, J., Wisniewski, H. M. and Soltysiak, Z. (1998). Regionand cell-type-specific pattern of tau phosphorylation in dog brain. Brain Res 802, 259-266.

Wenk, G. L., Zajaczkowski, W. and Danysz, W. (1997). Neuroprotection of acetylcholinergic basal forebrain neurons by memantine and neurokinin B. Behav Brain Res 83, 129-133.

Westerman, M. A., Cooper-Blacketer, D., Mariash, A. et al. (2002). The relationship between Abeta and memory in the 
Tg2576 mouse model of Alzheimer's disease. J Neurosci 22, 1858-1867.

Weuve, J., Kang, J. H., Manson, J. E. et al. (2004). Physical activity, including walking, and cognitive function in older women. JAMA 292, 1454-1461. http://dx.doi.org/10.1001/ jama.292.12.1454

Wienrich, M., Meier, D., Ensinger, H. A. et al. (2001). Pharmacodynamic profile of the M1 agonist talsaclidine in animals and man. Life Sci 68, 2593-2600.

Wiessner, C., Wiederhold, K. H., Tissot, A. C. et al. (2011). The second-generation active Abeta immunotherapy CAD106 reduces amyloid accumulation in APP transgenic mice while minimizing potential side effects. J Neurosci 31, 9323-9331. http://dx.doi.org/10.1523/JNEUROSCI.0293-11.2011

Wilbur, J., Marquez, D. X., Fogg, L. et al. (2012). The relationship between physical activity and cognition in older Latinos. J Gerontol B Psychol Sci Soc Sci 67, 525-534. http://dx.doi. org/10.1093/geronb/gbr137

Wilcock, G. K., Lilienfeld, S. and Gaens, E. (2000). Efficacy and safety of galantamine in patients with mild to moderate Alzheimer's disease: Multicentre randomised controlled trial. Galantamine International-1 Study Group. BMJ 321, 1445-1449.

Wiley, R. G., Oeltmann, T. N. and Lappi, D.A. (1991). Immunolesioning: Selective destruction of neurons using immunotoxin to rat NGF receptor. Brain Res 562, 149-153.

Wilkins, R. H. and Brody, I. A. (1969). Alzheimer's disease. Arch Neurol 21, 109-110.

Wolfe, M. S. (2006). The gamma-secretase complex: Membraneembedded proteolytic ensemble. Biochemistry 45, 7931-7939. http://dx.doi.org/10.1021/bi060799c

Wood, J. G., Mirra, S. S., Pollock, N. J. et al. (1986). Neurofibrillary tangles of Alzheimer disease share antigenic determinants with the axonal microtubule-associated protein tau (tau). Proc Natl Acad Sci U S A 83, 4040-4043.

Woodruff-Pak, D. S., Agelan, A. and Del Valle, L. (2007). A rabbit model of Alzheimer's disease: Valid at neuropathological, cognitive, and therapeutic levels. J Alzheimers Dis 11, 371-383.

Woodruff-Pak, D. S. (2008). Animal models of Alzheimer's disease: Therapeutic implications. J Alzheimers Dis 15, 507-521.

Wu, C. C., Chawla, F., Games, D. et al. (2004). Selective vulnerability of dentate granule cells prior to amyloid deposition in PDAPP mice: Digital morphometric analyses. Proc Natl Acad Sci U S A 101, 7141-7146. http://dx.doi.org/10.1073/ pnas.0402147101

Wyss-Coray, T., Masliah, E., Mallory, M. et al. (1997). Amyloidogenic role of cytokine TGF-beta1 in transgenic mice and in Alzheimer's disease. Nature 389, 603-606. http://dx.doi. org/10.1038/39321

Yotter, R. A., Doshi, J., Clark, V. et al. (2013). Memory decline shows stronger associations with estimated spatial patterns of amyloid deposition progression than total amyloid burden. $\mathrm{Neu}$ robiol Aging 34, 2835-2842. http://dx.doi.org/10.1016/j.neurobiolaging.2013.05.030

Zajaczkowski, W., Quack, G. and Danysz, W. (1996). Infusion of (+) -MK-801 and memantine - contrasting effects on radial maze learning in rats with entorhinal cortex lesion. Eur J Pharmacol 296, 239-246.

Zarit, S. H., Reever, K. E. and Bach-Peterson, J. (1980). Relatives of the impaired elderly: Correlates of feelings of burden. Gerontologist 20, 649-655.

Zarit, S. H., Todd, P. A. and Zarit, J. M. (1986). Subjective burden of husbands and wives as caregivers: A longitudinal study. Gerontologist 26, 260-266.

Zhang, T., Zhang, J., Derreumaux, P. et al. (2013a). Molecular mechanism of the inhibition of EGCG on the Alzheimer Abeta(1-42) dimer. J Phys Chem B 117, 3993-4002. http://dx.doi. org/10.1021/jp312573y

Zhang, Y., Pak, C., Han, Y. et al. (2013b). Rapid single-step induction of functional neurons from human pluripotent stem cells. Neuron 78, 785-798. http://dx.doi.org/10.1016/ j.neuron.2013.05.029

\section{Correspondence to}

Sarah E. Cavanaugh, PhD

Physicians Committee for Responsible Medicine 5100 Wisconsin Ave. NW

Suite 400

Washington, DC 20016, USA

Phone: 202-527-7389

Fax: 202-527-7489

e-mail: scavanaugh@pcrm.org 